\title{
Riboflavin: The Health Benefits of a Forgotten Natural Vitamin
}

\author{
Nittiya Suwannasom ${ }^{1,2}\left(\mathbb{D}\right.$, Ijad Kao ${ }^{1}$, Axel Pruß ${ }^{1}$, Radostina Georgieva ${ }^{1,3}$ (D) \\ and Hans Bäumler $1, * \mathbb{D}$ \\ 1 Institute of Transfusion Medicine, Center of Tumor Medicine, Charité-Universitätsmedizin Berlin, \\ Charitéplatz 1, 10117 Berlin, Germany; nittiya.suwannasom@charite.de (N.S.); ijad.kao@charite.de (I.K.); \\ axel.pruss@charite.de (A.P.); radostina.georgieva@charite.de (R.G.) \\ 2 School of Medical Sciences, University of Phayao, Phayao 56000, Thailand \\ 3 Biophysics and Radiology, Department of Medical Physics, Faculty of Medicine, Trakia University, \\ 6000 Stara Zagora, Bulgaria \\ * Correspondence: hans.baeumler@charite.de
}

Received: 3 January 2020; Accepted: 29 January 2020; Published: 31 January 2020

\begin{abstract}
Riboflavin (RF) is a water-soluble member of the B-vitamin family. Sufficient dietary and supplemental RF intake appears to have a protective effect on various medical conditions such as sepsis, ischemia etc., while it also contributes to the reduction in the risk of some forms of cancer in humans. These biological effects of RF have been widely studied for their anti-oxidant, anti-aging, anti-inflammatory, anti-nociceptive and anti-cancer properties. Moreover, the combination of RF and other compounds or drugs can have a wide variety of effects and protective properties, and diminish the toxic effect of drugs in several treatments. Research has been done in order to review the latest findings about the link between RF and different clinical aberrations. Since further studies have been published in this field, it is appropriate to consider a re-evaluation of the importance of RF in terms of its beneficial properties.
\end{abstract}

Keywords: riboflavin; vitamin B2; complementary medicine; functional food; oxidative stress; cancer; neurodegeneration; muscular degeneration

\section{Introduction}

Riboflavin (RF) was first documented in 1879 by Blythto as a yellow pigment found in milk [1]. $\mathrm{RF}$, chemically, is 7, 8-dimethyl-10-ribityl-isoalloxazine which consists of a flavin isoalloxazine ring bound to a sugar side chain, Ribitol [2]. RF is also known as an essential vitamin $B_{2}$, a water-soluble vitamin, is heat stable. Cooking does not lower levels of $\mathrm{RF}$, however exposure to light could destroy it. $\mathrm{RF}$ can be found in a wide variety of foods and natural sources, especially milk, organ meats-mostly in calf liver, egg, fish, nuts, certain fruits and legumes, wild rice, mushrooms, dark green leafy vegetables, yeast, beer, cheese and dietary products $[1,3]$. RF is poorly stored by vertebrates because of its limited absorption in humans. Therefore, orally supplied RF by a healthy diet is required to avoid ariboflavinosis which causes cheilitis, sore tongue, and a scaly rash on the scrotum or vulva. RF causes no known toxicity, since at higher intakes it is excreted in the urine and not stored [3]. RF is found in different concentrations in various human body fluids and organs (Table 1). Recent analytical procedures developed for detection of RF in biological samples were described in several reviews [4-6].

$\mathrm{RF}$ is phosphorylated intracellular to flavin mononucleotide (FMN) and further metabolized to flavin adenine dinucleotide (FAD) (Figure 1).

Both FMN and FAD play a key role as cofactors in energy metabolism and are required for co-enzyme function in numerous oxidation and reduction reactions in all aerobic forms of life. RF has 
been used in dietary supplements and for inflammatory disease treatments such as angulus infectious, cheilitis, glossitis [7], sepsis [8,9], cataracts and migraine headaches [3] (Figure 2).

Table 1. Flavin content of selected human body fluids $\left(\mathrm{mol} \mathrm{L}^{-1}\right)$ and organs (mol per kg of dry matter) [1].

\begin{tabular}{cccc}
\hline & Riboflavin & FAD & FMN \\
\hline Skin & $7.6 \times 10^{-6}$ & - & - \\
Cerebral cortex & $7.2 \times 10^{-6}$ & - & - \\
Myocardium & $3.2 \times 10^{-5}$ & - & - \\
Pectoral muscle & $7.2 \times 10^{-6}$ & - & - \\
Aortic tissue & $4.8 \times 10^{-7}$ & $9.7 \times 10^{-7}$ & $2.2 \times 10^{-7}$ \\
Erythrocyte & $1.4 \times 10^{-7}$ & $4.3 \times 10^{-7}$ & $2.8 \times 10^{-8}$ \\
Plasma & $1.0 \times 10^{-8}$ & $6.3 \times 10^{-8}$ & $7.5 \times 10^{-9}$ \\
Eye-fluid & $4.5 \times 10^{-6}$ & - & - \\
\hline
\end{tabular}

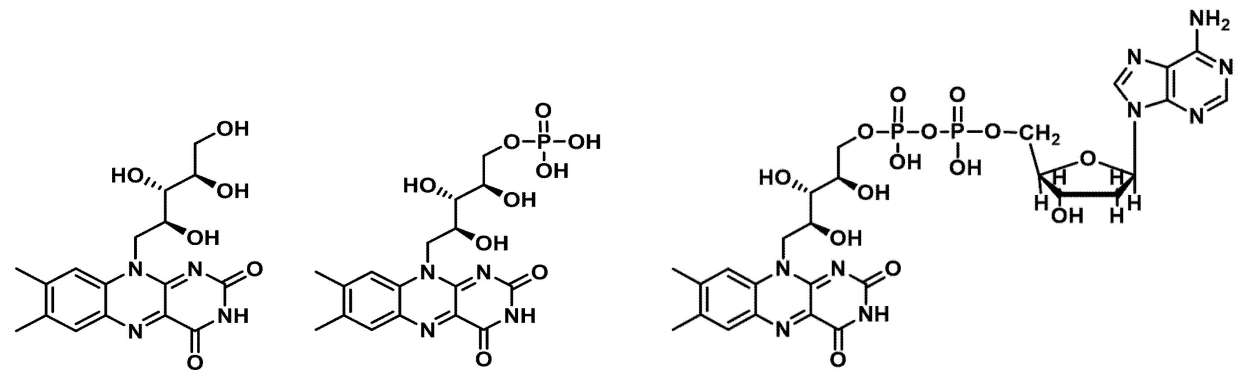

(a)

(b)

(c)

Figure 1. Structure of (a) Riboflavin (RF), (b) Flavin monophosphate (FMN), and (c) Flavin adenine dinucleotide (FAD). ChemDraw (PerkinElmer Informatics, Inc. MA, USA).

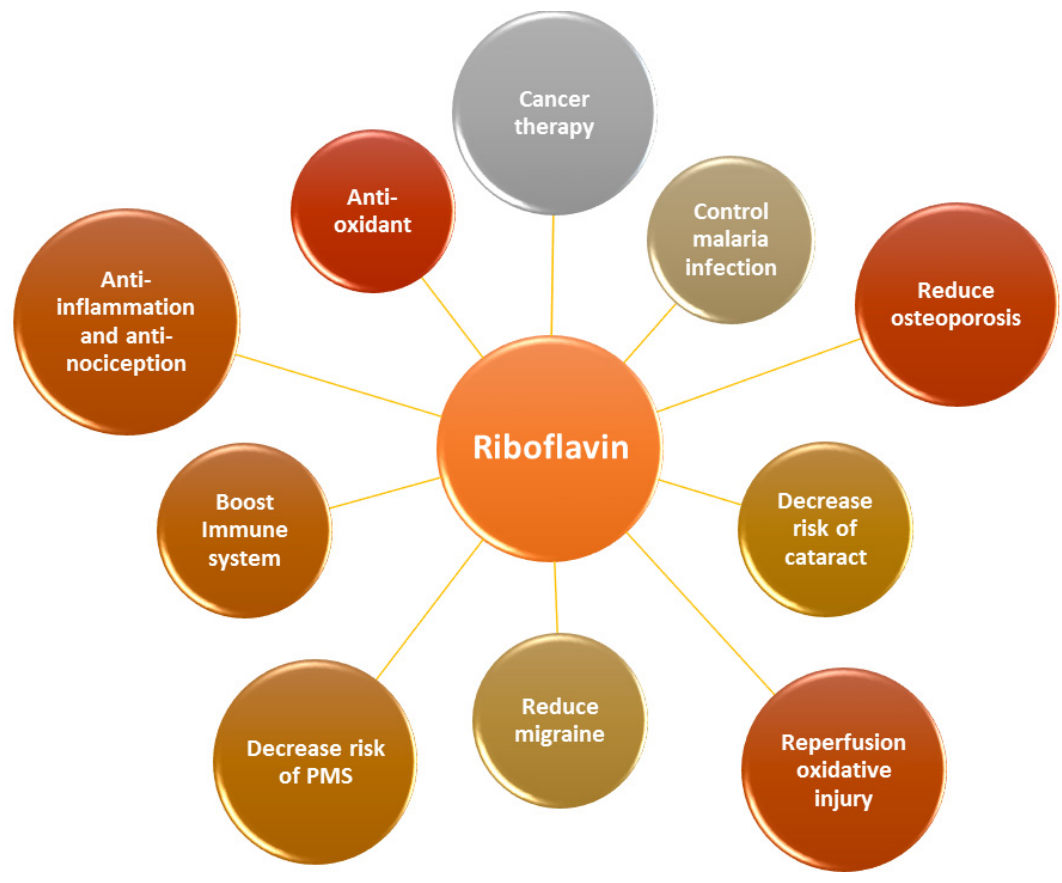

Figure 2. RF is an essential vitamin for multiple physiological aspects in the body.

\section{Beneficial Health Effects of RF}

\subsection{Antioxidant Properties}

Oxidative stress plays a crucial functional role in the pathogenesis of various human disease states including ischemia-reperfusion injury, diabetes and angina pectoris [10]. Oxidative stress is 
a key effect of aging and degenerative diseases along with aging. The authors have demonstrated that supplementation of RF significantly extended the lifetime and strengthened the reproduction of fruit flies via enhancing the activity of antioxidant enzymes [11]. RF also activates the synthesis of a normal extracellular matrix and reduces reactive oxygen species (ROS) levels in keratoconus [12]. The evidence of the effect of RF and its roles for reactive oxygen species in various symptoms and diseases is summarized in Table 2.

RF was used for its potent antioxidant and anti-inflammatory effects in the ischaemic liver, protecting hepatic parenchymal cells against I/R injury [13].

Other antioxidant enzymes concentrations-like superoxide dismutase (SOD), catalase and glutathione peroxidase-are also influenced by RF concentration. RF plays an important role for the antioxidant status inside cell systems as well as being part of the glutathione reductase (GR) and xanthine oxidase system. RF in the form of FAD is necessary for GR enzyme to convert oxidized glutathione (GSSG) to the reduced glutathione (GSH) (Figure 3). It then functions as an endogenous antioxidant in different cells [14].

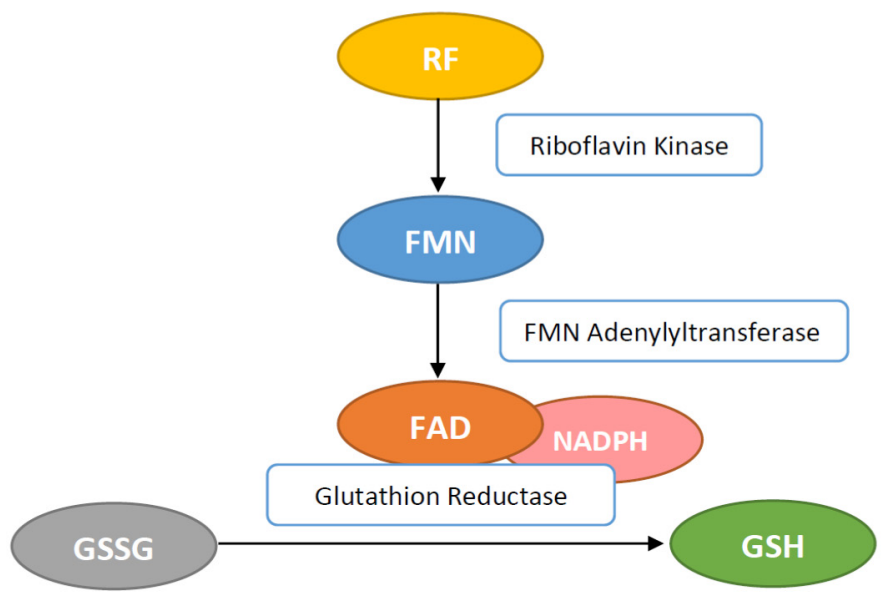

Figure 3. Flavin adenine dinucleotide (FAD) activates the glutathione reductase (GR) by transferring hydrogen for conversion of glutathione disulfide (GSSG) to glutathione (GSH).

\subsection{Reperfusion Oxidative Injury}

Reperfusion oxidative injuries refer to the tissue damages which occur after ischemia when free radicals and inflammatory cytokines are increased (Table 3). RF can attenuate oxidative injuries through its ability to scavenge free radicals and therefore decrease re-oxygenation injuries. New evidence suggests that ROS have a crucial role in the pathogenesis of ischemia/reperfusion injury. Studies in various cell cultures and animal species have shown a variety of protective actions of RF in many organs, e.g., the neuroprotective effect of cerebral ischemia [15]. The authors showed that pre-treatment of the SH-SY5Y cells with RF before oxygen glucose deprivation (OGD) experiments significantly reduced the OGD-induced lactate dehydrogenase $(\mathrm{LDH})$ release and significantly increased cell viability. The cell viability and LDH secretion were quantified in the SH-SY5Y cell line and cortical neuron cultures using the cell counting Kit-8 and the LDH quantification kit compared to that treated-OGD group. In vivo study showed a significant neuroprotective activity via the modulation of the miR-203/c-Jun signalling pathway [15].

RF can significantly protect against oxidant-mediated inflammatory injury in the lungs of Long-Evans rats caused by cobra venom factor or IgG immune complexes, or ischemia-perfusion [24]. RF has also been reported to have a protective role in focal ischemia with decreasing brain injury and oedema formation in rats [25]. RF also has cardio-protective effects in isolated rabbit cardiomyocytes, reducing elevated ferrylmyoglobulin induced by cardiac re-oxygenation damage. This effect is mediated by Flavin reductase [26]. 
Table 2. Evidence on effect of RF and its roles for reactive oxygen species in various symptoms and diseases. Upregulation $\uparrow$, downregulation $\downarrow$.

\begin{tabular}{|c|c|c|c|c|}
\hline Model & Dose & Antioxidant Enzymes & Key Findings & References \\
\hline $\begin{array}{l}\text { Anti-aging in } \\
\text { Drosophila } \\
\text { melanogaster (fruit fly) }\end{array}$ & $\mathrm{RF}$ at $120 \mu \mathrm{g} / \mathrm{mL}$ & $\begin{array}{r}\text { SOD1 } 1 ; \text {; CAT } \uparrow ; \\
\text { lipofuscin (LF) } \downarrow\end{array}$ & $\begin{array}{l}\text { RF prolonged the life span and increased reproductive capacity } \\
\text { through anti-oxidative stress pathway involving enhancing the } \\
\text { activity of SOD1 and CAT and inhibiting } \\
\text { lipofuscin accumulation }\end{array}$ & [11] \\
\hline $\begin{array}{l}\text { Keratoconus corneal } \\
\text { stroma cells }\end{array}$ & $\begin{array}{l}\text { Keratoconus cells were treated } \\
\text { with low dose of RF at } \\
0.167 \mu \mathrm{g} / \mathrm{mL}\end{array}$ & $\begin{array}{l}\text { Increasing gene expression } \\
\text { of antioxidant enzymes: } \\
\text { aldehyde dehydrogenase } \\
\text { 3A1, CAT, enolase } 1, \mathrm{GPx} 1 \text {, } \\
\text { haem oxygenase } 1, \text { SOD } 1 \\
\text { and transketolase }\end{array}$ & $\begin{array}{l}\text { RF improved the synthesis of a normal extracellular matrix and } \\
\text { downregulated ROS level in keratoconus. It was quatified by } \\
\text { the total collagen protein in the keratoconic stroma. }\end{array}$ & [12] \\
\hline $\begin{array}{l}\text { Diabetes-induced } \\
\text { cardiac dysfunction }\end{array}$ & $\begin{array}{l}\mathrm{RF} \text { at } 20 \mathrm{mg} / \mathrm{kg} \text { was treated after } \\
\text { streptozotocin-induced diabetes } \\
\text { type I. }\end{array}$ & $\begin{array}{l}\mathrm{SOD} \uparrow, \mathrm{MDA} \downarrow, \mathrm{HO}-1 \\
\text { protein level } \uparrow\end{array}$ & $\begin{array}{l}\text { RFK can reduced the risk of cardiac dysfunction by increasing } \\
\text { antioxidant, HO- } 1 \text { and decreasing CTGF levels as well as } \\
\text { improving lipid profile }\end{array}$ & [16] \\
\hline $\begin{array}{l}\text { Diabetes mellitus } \\
\text { type-2 }\end{array}$ & $\begin{array}{l}\mathrm{RF} \text { at } 10 \text { and } 20 \mathrm{mg} / \mathrm{kg} \text { was } \\
\text { treated after alloxan-induced } \\
\mathrm{DM}\end{array}$ & $\begin{array}{l}\text { SOD } \uparrow, \text { catalase } \uparrow, \\
\text { GSH } \uparrow, \text { MDA } \downarrow\end{array}$ & $\begin{array}{l}\text { Decreased pancreatic activity, restored ant-oxidant enzyme } \\
\text { activity, decreased FBG level while calcium level and GLUT- } 4 \\
\text { expression was increased }\end{array}$ & [17] \\
\hline $\begin{array}{l}\text { Cardiac abnormalities } \\
\text { in experimental } \\
\text { atherosclerosis in rat }\end{array}$ & $\begin{array}{l}\mathrm{RF} \text { at } 40 \mathrm{mg} / \mathrm{kg} \text { together with } \\
\text { CoRNS after hypolipidemic } \\
\text { induction }\end{array}$ & $\mathrm{SOD} \uparrow, \mathrm{CAT} \uparrow, \mathrm{GPx} \uparrow$ & $\begin{array}{l}\text { CoRNS significant reduced lipid profile: LDL and cardiac } \\
\text { enzymes (LDH, ALT, AST, ALP) with enhanced levels of HDL } \\
\text { and antioxidants. }\end{array}$ & [18] \\
\hline Migraine model & $\begin{array}{l}\text { RF } 100 \mathrm{mg} / \mathrm{kg} \text { was treated before } \\
\text { GTN-induced migraine }\end{array}$ & Lipid peroxidation $\downarrow, \mathrm{GSH} \uparrow$ & $\begin{array}{l}\text { RF and vitamin E had a protective effect on the GTN-induced } \\
\text { brain injury by inhibiting free radical production, regulation of } \\
\text { calcium-dependent processes, and supporting the antioxidant } \\
\text { redox system. }\end{array}$ & [20] \\
\hline
\end{tabular}

Table 3. Evidence of RF on the attenuation of reperfusion oxidative injury.

\begin{tabular}{cccc}
\hline Model & RF Dose & Key findings & Conclusions \\
\hline $\begin{array}{c}\text { Stroke-induced brain } \\
\text { damage (neuroprotection } \\
\text { against excitotoxicity) }\end{array}$ & $\begin{array}{c}\text { RF at 0.05-0.5 mM before } \\
\text { glutamate or NMDA } \\
\text { treatment }\end{array}$ & $\begin{array}{c}\text { RF at the concentrations of 0.2, 0.3, } \\
\text { and 0.4 mM were significantly } \\
\text { neuroprotective against glutamate } \\
\text { and NMDA. }\end{array}$ & $\begin{array}{c}\text { RF ameliorate glutamate or } \\
\text { NMDA-mediated excitotoxicity } \\
\text { to CGCs }\end{array}$ \\
\hline $\begin{array}{c}\text { Cortical contusion } \\
\text { injury (CCI) }\end{array}$ & $\begin{array}{c}\text { RF treatment with } 7.5 \mathrm{mg} / \mathrm{kg}, \\
\text { i.p; } \mathrm{n}=7,15 \mathrm{~min} \text { after injury. } \\
\text { A second dose was applied } \\
\text { after } 24 \mathrm{~h} \text { after injury. }\end{array}$ & $\begin{array}{c}\text { Reducing brain edema formation, } \\
\text { and inhibit GFAP+ expression, improve } \\
\text { behavioral function. }\end{array}$ & $\begin{array}{c}\text { Administration of RF following CCI } \\
\text { of the frontal cortex improves } \\
\text { recovery of function following injury }\end{array}$ \\
\hline $\begin{array}{c}\text { Cortical contusion } \\
\text { injury (CCI). }\end{array}$ & $\begin{array}{c}\text { RF was treated after CCI:a } \\
\text { combination of } 1 \mathrm{mmol} / \mathrm{kg} \\
\mathrm{MgCl} \text { and } 7.5 \mathrm{mg} / \mathrm{kg} \mathrm{RF}\end{array}$ & $\begin{array}{c}\text { The combination of } \mathrm{MgCl}_{2} \text { and RF } \\
\text { improved the functional recovery while } \\
\text { the half-dose combination did not. }\end{array}$ & $\begin{array}{c}\text { RF and magnesium infusions } \\
\text { improved functional recovery to a } \\
\text { greater extent than either alone } \\
\text { following a frontal cortical contusion } \\
\text { injury in rats }\end{array}$ \\
\hline [23]
\end{tabular}

\subsection{Malaria Infection}

Infections with malaria parasites may stimulate the immune system leading to ROS formation, which can attack the plasma membrane of the erythrocyte compromising its integrity [27]. RF reduced the level of methaemoglobin content, decreased food vacuole size and inhibited asexual parasite growth in erythrocytes infested with P. falciparum [28].

In addition, co-treatment of RF and Chloroquine tablets against malaria infection significantly increased the packed cell volume and haemoglobin $(\mathrm{Hb})$ levels, but reduced lipid peroxidation, contributing to maintaining the redox integrity of cells, protecting them against ROS generated during the inflammatory response [29].

\subsection{Immune System}

RF activates phagocytic activity of neutrophils and macrophages, and stimulates the multiplication of neutrophils and monocytes [30]. It has also been shown that RF is important for the survival of macrophage RAW 264.7 cells. The reduction in RF concentration resulted in a decreased rate of cell proliferation [31]. A combined supplementation-consisting of RF, delta-tocotrienol and quercetin-improved the inhibition of serum tumor necrosis factor alpha (TNF- $\alpha$ ) and nitric oxide (NO) levels in a chicken model [32].

However, RF administration affects neutrophil migration, inhibiting the infiltration and accumulation of activated granulocytes into peripheral sites, which may lead to a decreased 
inflammatory influx and, thereby, a decrease in inflammatory symptoms [33]. RF is a potential substance for use in virus inactivation, or as an adjuvant in chemo radiotherapy for cancer treatment because of its toxicological and photosensitizing attributes. RF suppressed T-cells infiltration and donor-reactive alloantibody formation during the early period after allotransplantation [34].

The pro-inflammatory transcription nuclear factor kappa B (NF- $\mathrm{kB})$ is normally activated by degradation of inhibitory kappa B (ІкB). When this occurs, NF- $\mathrm{KB}$ translocates to the nucleus and binds to specific promoter regions of genes encoding pro-inflammatory proteins. Proteasomes are key regulators of lipopolysaccharide (LPS)-stimulated inflammatory signalling pathways. RF, as proteasome inhibitor, possibly down-regulates the NF-KB activation initiated by ROS, which are the potent activators of a plethora of general pro-inflammatory cytokines such as interleukin-6 (IL-6), TNF- $\alpha$, etc. Therefore, ultimately, as proteasome inhibitor RF suppresses the production of TNF- $\alpha$ and NO, and exerts anti-inflammatory effects by inhibiting NF- $\mathrm{KB}$, activation. As was recently reported, $\mathrm{RF}$ may protect against multitude of age-associated diseases by inhibition levels of secretion of TNF- $\alpha$, NO production, activation of NF- $\mathrm{kB}$, and degradation [35].

In recent years, there has been much interest in the anti-nociceptive and anti-inflammatory effects of RF (Table 4). RF helps in reducing inflammatory nociceptive pain [36,37]. Several animal models have been used to study the possible role in anti-nociceptive and anti-inflammatory effects of RF. It has been indicated that RF could inhibit nociceptive responses induced by a number of inflammatory agents in a variety of structures. For example, RF inhibited the formalin-induced hind paw oedema [37]. Moreover, RF can improve the anti-nociceptive effect when combined with low-dose morphine in a formalin test model [38], as well as in a zymosan-induced peritonitis model [39]. The anti-inflammatory studies of RF on the zymosan-induced peritonitis model showed that RF effects were dependent on the time of administration and dose [40], as well as strain-specific differences in mice [38].

Table 4. Antinociception and anti-inflammation effects of RF in animal model.

\begin{tabular}{|c|c|c|c|}
\hline Animal Model & RF Doses/Models & Major Outcome & References \\
\hline \multicolumn{4}{|c|}{ Inflammation-Related Pain } \\
\hline $\begin{array}{l}\text { Acetic acid-induced abdominal } \\
\text { constructions, formaldehyde-induced } \\
\text { nociceptive response and hot-plate } \\
\text { models in mice }\end{array}$ & $\begin{array}{l}\mathrm{RF} \text { at } 3-100 \mathrm{mg} / \mathrm{kg} \text { i.p. injection } 1 \mathrm{~h} \text { before acetic } \\
\text { acid-induced model, RF at } 6 \text { or } 12 \mathrm{mg} / \mathrm{kg} \text { i.p. injection } 1 \mathrm{~h} \\
\text { before formaldehyde-induced nociceptive response, } \\
\text { and } \mathrm{RF} \text { at } 50 \mathrm{mg} / \mathrm{kg} \text { i.p. injection } 1 \mathrm{~h} \text { before } \\
\text { formaldehyde-induced hindpaw edema }\end{array}$ & $\begin{array}{l}\text { A dose-dependent RF inhibited the nociceptive } \\
\text { response produced by acetic acid. Pre-treatment RF } \\
\text { remarkably reduced the acute nociceptive response } \\
\text { induced by formaldehyde in the second phase, } \\
\text { but not in the hot-plate model. RF moderately } \\
\text { inhibited formaldehyde-induced hindpaw edema. }\end{array}$ & [37] \\
\hline $\begin{array}{l}\text { Formalin-induced and } \\
\text { carrageenan-induced paw edema, } \\
\text { and spinal nerve ligation models in rat }\end{array}$ & $\begin{array}{c}\mathrm{RF} \text { at } 1-50 \mathrm{mg} / \mathrm{kg} \text { oral administration } 30 \mathrm{~min} \text { before } \\
\text { formalin test and } 6.25-150 \mathrm{mg} / \mathrm{kg} \text { immediately after } \\
\text { carrageenan injection }\end{array}$ & $\begin{array}{l}\text { Second phase treatment with RF produced a } \\
\text { significant dose-dependent inhibition in flinching } \\
\text { behavior produced by formalin and RF at } 25 \mathrm{mg} / \mathrm{kg} \\
\text { dose had peak antinociceptive effect in } \\
\text { formalin-induced model. RF reduced hyperalgesic } \\
\text { effect, highest effect at } 75 \mathrm{mg} / \mathrm{kg} \text { dose. In addition, } \\
\text { a dose- and time-dependent RF treatment reduced by } \\
\text { carrageenan-induced edema, but not tactile allodynia } \\
\text { in the spinal nerve ligation models. Moreover, } \\
\text { antinociceptive effect of RF can be reversed by } \\
\text { glibenclamide and NG-L-nitro-aeginie methyl ester. }\end{array}$ & [41] \\
\hline $\begin{array}{l}\text { Formalin-induced nociceptive response, } \\
\text { carrageenan-induced paw edema, } \\
\text { LPS-induced febrile response, and cotton } \\
\text { pellet-induced formation of fibrovascular } \\
\text { tissue models in rat }\end{array}$ & $\begin{array}{l}\mathrm{RF} \text { at } 25,50,100 \mathrm{mg} / \mathrm{kg} \text { i.p. injection } 30 \mathrm{~min} \text { before } \\
\text { formalin-induced nociceptive response, } \\
\text { carrageenan-induced paw edema, RF at } 50 \text { or } 100 \mathrm{mg} / \mathrm{kg} \\
\text { immediately or } 2 \mathrm{hr} \text { after LPS-induced the febrile response, } \\
\text { and RF at } 50 \mathrm{or} 100 \mathrm{mg} / \mathrm{kg} \text { i.p. } 7 \text { days after s.c. } \\
\text { implantation of a cotton pellet-induced fibrovascular tissue }\end{array}$ & $\begin{array}{l}\text { RF inhibited the nociceptive response in the mouse } \\
\text { formalin test, markedly in second phase. RF was } \\
\text { dose-dependently reduced the mechanical allodynia } \\
\text { and the paw edema induced by carrageenan and } \\
\text { inhibited the fever induced by LPS. Moreover, } \\
\text { the formation of fibrovascular tissue induced by s.c. } \\
\text { implant of a cotton pellet was inhibited. Therefore, } \\
\text { RF prevents prolonged inflammatory response. }\end{array}$ & [36] \\
\hline $\begin{array}{l}\text { Zymosan-induced peritonitis in } \\
\text { Swiss mice }\end{array}$ & $\begin{array}{c}\mathrm{RF} \text { at } 20,50,100 \mathrm{mg} / \mathrm{kg} \text { i.p. injection } 30 \mathrm{~min} \text { before } \\
\text { zymosan administration; RF at } 50 \mathrm{mg} / \mathrm{kg} \text { in combination } \\
\text { with } 5 \mathrm{mg} / \mathrm{kg} \text { morphine }\end{array}$ & $\begin{array}{l}\text { RF at } 50 \text { and } 100 \mathrm{mg} / \mathrm{kg} \text { induced } \\
\text { antinociceptive-related body writhes and RF at } \\
100 \mathrm{mg} / \mathrm{kg} \text { dose suppressed intraperitoneal PMN } \\
\text { influx. On the other hand, RF co-injected with } \\
\text { morphine at low dose had antinociceptive effect and } \\
\text { also reduced levels of proinflammatory cytikines } \\
\text { such as TNF- } \alpha \text {, IL-12p07, and IFN- } \gamma \text { according to RF } \\
\text { dose and the time of injection. }\end{array}$ & [39] \\
\hline \multicolumn{4}{|c|}{ Anti-Inflammatory Effect } \\
\hline $\begin{array}{l}\text { Toxin-induced shock (LPS-induced shock } \\
\text { and S. aureus enterotoxin B (SEB)-induced } \\
\text { shock) and bacterial infection in mice }\end{array}$ & $\begin{array}{c}\mathrm{RF} \text { at } 2.5,5,10 \text {, and } 20 \mathrm{mg} / \mathrm{kg} \text { bolus injection } 6 \mathrm{~h} \text { after LPS } \\
\text { injection or SEB-D-galactosamine injection. RF at } 2.5,5,10, \\
20 \mathrm{mg} / \mathrm{kg} 1 \text { day before } E \text {. coli inoculation or } 1 \text { and } 2 \text { days } \\
\text { after } S . \text { aureus inoculation. }\end{array}$ & $\begin{array}{l}\text { RF decreased the mortality of endotoxin- and } \\
\text { exotoxin-induced shock, gram-negative and } \\
\text { gram-positive bacterial infection including long-term } \\
\text { treatment. In addition, RF reduced levels of plasma } \\
\text { inflammatory cytokines, including TNF-, IL-1 } 1 \beta \text {, IL-6, } \\
\text { IFN- } \gamma \text {, MCP-1, MIP-2, and NO level. Moreover, } \\
\text { co-administration RF with APC ameliorated survival } \\
\text { rate of toxin-induced shock. }\end{array}$ & [42] \\
\hline
\end{tabular}


Table 4. Cont.

\begin{tabular}{|c|c|c|c|}
\hline Animal Model & RF Doses/Models & Major Outcome & References \\
\hline \multicolumn{4}{|c|}{ Inflammation-Related Pain } \\
\hline $\begin{array}{l}\text { LPS-induced shock model and bacterial } \\
\text { infection model in mice }\end{array}$ & $\begin{array}{c}\mathrm{RF} \text { at } 2.5,5,10,20,40, \text { and } 80 \mathrm{mg} / \mathrm{kg} / 6 \mathrm{~h} \mathrm{i.v.} \mathrm{infusion} \mathrm{after} \\
6 \mathrm{~h} \mathrm{LPS} \text { injection. RF at } 80 \mathrm{mg} / \mathrm{kg} / 6 \mathrm{~h} \text { after } 1 \mathrm{~h} \text { E.coli } \\
\text { infection or RF at } 20,40,80 \mathrm{mg} / \mathrm{kg} / 6 \mathrm{~h} \text { after } 1 \mathrm{~h} \\
\text { S.aureus infection. }\end{array}$ & $\begin{array}{l}\text { RF protected mice against the mortality in both toxin } \\
\text { shock and infection models, but RF reduced only the } \\
\text { level of IL- } 6 \text { and NO in plasma. In addition, RF } \\
\text { decreased the elevation of TNF- } \alpha \text {, IL-1 } \beta, \text { MPC-1, } \\
\text { IL- } 6 \text {, and NO level in plasma. }\end{array}$ & [8] \\
\hline LPS-induced shock model in mice & $\begin{array}{c}\mathrm{RF} \text { at } 2.5 \text { or } 10 \mathrm{mg} / \mathrm{kg} \text { for } 6 \mathrm{~h} \text { continuous i.v bolus } \\
\text { administration with or without aminolevane }{ }^{\circledR} \text { or single } \\
\text { dose injection with or without amino acids or valine after } \\
6 \mathrm{~h} \text { LPS injection. }\end{array}$ & $\begin{array}{l}\mathrm{RF} \text { at } 10 \mathrm{mg} / \mathrm{kg} \text { administered continuously for } 6 \mathrm{~h} \\
\text { reduced morbidities on LPS- induced shock model, } \\
\text { and was better with aminolevane }{ }^{\circledR} \text { combination } \\
\text { treatment. RF treatment in combination with } \\
\text { tryptophan, isoleucine, proline, threonine, alanine or } \\
\text { valine had improved the survival rate, but only } \\
\text { valine was significantly effective. Moreover, RF } \\
\text { reduced IL-6, lactic acid level, but increased } \\
\text { glucose level. }\end{array}$ & [9] \\
\hline Endotoxin-induced shock in mice & $\mathrm{RF}$ at $20 \mathrm{mg} / \mathrm{kg}$ i.v. administered after $6 \mathrm{~h}$ LPS injection & $\begin{array}{l}\text { RF decreased the number of IL- } 6 \text { and MIP-2 and NO } \\
\text { levels in plasma. RF also reduced IL-6 and MIP-2 } \\
\text { levels in lung, but inhibited only MIP-2 level in liver. } \\
\text { However, RF reduced IL-6 mRNA expression in lung, } \\
\text { but MIP-2 mRNA expression was inhibited in liver } \\
\text { and kidney. Additionally, iNO expression was } \\
\text { inhibited by RF. }\end{array}$ & [43] \\
\hline $\begin{array}{l}\text { Olive oil-triggered paw swelling and } \\
\text { collagen-induced arthritis models in mice }\end{array}$ & $\begin{array}{c}\mathrm{RF} \text { at } 20 \mathrm{mg} / \mathrm{kg} \text { i.p. administration before oil injection or } \\
\text { after collagen-induced arthritis }\end{array}$ & $\begin{array}{l}\text { RF inhibited the paw swelling induced by olive oil, } \\
\text { affecting a reduction in neutrophil-dependent } \\
\text { reaction. However, RF could not inhibit delayed type } \\
\text { hypersensitivity reactivity and collagen II arthritis. }\end{array}$ & [33] \\
\hline LPS-induced shock model in mice & $\begin{array}{c}\text { RF at } 1 \text { and } 10 \mathrm{mg} / \mathrm{kg} \text { i.p. injection at } 2 \text { and } 0 \mathrm{~h} \text { before } \\
\text { LPS administration }\end{array}$ & $\begin{array}{l}\text { RF significantly suppressed the LPS-induced } \\
\text { lethality in mice septic shock model and RF have } \\
\text { protective effect through up-regulated the expression } \\
\text { of HSP25 in the lung and heart. }\end{array}$ & [44] \\
\hline $\begin{array}{l}\text { Zymosan-induced peritonitis in different } \\
\text { C57BL/6J, BALB/c and CBA mice strains }\end{array}$ & RF at $50 \mathrm{mg} / \mathrm{kg}$ i.p. co-injection with zymosan $(40 \mathrm{mg} / \mathrm{kg}$ ) & $\begin{array}{c}\text { RF co-treatment with zymosan reduced pain } \\
\text { symptoms. Anti-inflammatory effects of RF are } \\
\text { strain-specific manner. Particularly, peritoneal } \\
\text { leukocytes (PTL) accumulation was inhibited in } \\
\text { BALB/c and CBA strains, but was prolonged in } \\
\text { C57BL/6J strain. The expression of iNOS was } \\
\text { delayed (C57BL/6J) or inhibited (BALB/c and CBA) } \\
\text { in PTL lysates as well as the prolonged (C57BL/6) or } \\
\text { inhibited (BALB/c) intraperitoneal accumulation } \\
\text { of MMP-9. }\end{array}$ & [38] \\
\hline $\begin{array}{l}\text { Zymosan-induced peritonitis in } \\
\text { Swiss mice }\end{array}$ & $\begin{array}{l}\mathrm{RF} \text { at } 0,20,50 \text {, or } 100 \mathrm{mg} / \mathrm{kg} \text { by co-injection, pre-injection } \\
\text { or post-injection in zymosan-induced peritonitis }\end{array}$ & $\begin{array}{l}\text { RF itself induced nociceptive-related body writhes, } \\
\text { but effectively reduces zymosan-induced writhing } \\
\text { response on influence of pre-injection or post- } \\
\text { injection. RF also reduced the evaluation number of } \\
\text { PLTs, mainly PMN and an increase in } \\
\text { inflammation-related cytokines and MMP- } 9 \text { with } \\
\text { dose- and administration time-dependent effect. }\end{array}$ & [40] \\
\hline LPS-induced acute lungs injury in rat & $\begin{array}{l}\text { RF at } 30 \mathrm{mg} / \mathrm{kg} \text {, p.o. for } 7 \text { days before LPS } \\
\text { intranasally (i.n.) }\end{array}$ & $\begin{array}{c}\text { RF reduced interstitial edema, hemorrhage, } \\
\text { infiltration of inflammatory PMNs, and destruction } \\
\text { of lung parenchyma as well as decreased the iNOS } \\
\text { level, but enhanced GSH, GR, GRx, } \\
\text { and CAT expression. }\end{array}$ & [45] \\
\hline $\begin{array}{l}\text { Zymosan-induced inflammation in mice } \\
\text { and in vitro macrophages }\end{array}$ & $\begin{array}{c}\mathrm{RF} \text { at } 50 \mathrm{mg} / \mathrm{kg} \text { i.p. injection } 30 \mathrm{~min} \text { either before zymosan, } \\
\text { together with zymosan, or 2, 4, } 6 \text { h after i.p. zymosan } \\
\text { injection. }\end{array}$ & $\begin{array}{l}\text { RF causes both the inhibition of expression and } \\
\text { release of HMGB1 in time-dependent manner. }\end{array}$ & [46] \\
\hline
\end{tabular}

Another study showed that oral administration of RF reduced inflammation and nociception, which were induced by formalin via the activation of ATP-sensitive $\mathrm{K}^{+}$- channels or NO release [41].

Sepsis is attributed to a systemic inflammatory response to bacterial infection, leading to multiple system dysfunctions in the body. Many pro-inflammatory mediators play a role in immune reaction during septic shock with release of inflammation cytokines, e.g., TNF- $\alpha$, IL-1, IL-6, chemokines (monocyte chemo attractant protein 1 (MCP-1), macrophage inflammatory protein (MIP-2)), and NO production, including high-mobility group protein B1 (HMGB1) [47]. The beneficial effects of RF are based on its anti-inflammatory capability. Several experimental animal models have shown that RF has a potent effect against mortality rates from LPS-induced septic shock, exotoxin and exotoxin-induced shock, Gram-positive and Gram-negative bacterial infections via reduction the elevated level of TNF- $\alpha$, IL-1, IL-1 $\beta$, IL-6, gamma interferon (IFN- $\gamma$ ), MCP-1, and 2 MIP-2 as well as NO levels [8,42,43].

In terms of the efficacy of treatment with RF in combination with antibiotics (ampicillin [48,49], azithromycin [50], Ciprofloxacin [49]) or amino acids [8] on septic arthritis, RF has been reported as causing an increase in the survival rate of mice [50].

Therefore, RF might represent a promising new therapeutic strategy for the treatment of sepsis and septic shock. However, to our knowledge, there are a limited number of studies that have examined the anti-inflammatory and anti-nociceptive effects of RF in humans. Most of the evidence that RF reduces inflammation and nociception responses comes from laboratory animal studies. It has been 
demonstrated that RF reduced the hepatocellular injury and hepatotoxicity induced by LPS through elevation of malondialdehyde (MDA) level and myeloperoxidase (MPO) activity, whereas a marked decrease in GSH content, GR and glutathione peroxidase (GPx) activity. Moreover, expression of inducible nitric oxide synthase (iNOS) and catalase (CAT) gene expression was improved via RF administration [45]. In addition, RF reduces mortality rates through the reduction of the expression and release of high-mobility group protein B1 (HMGB1); however, the effect of RF was time-dependent [46]. A high dose of RF was also indicated to decrease LPS-induced mortality by increasing the expression of heat shock protein 25 (HSP25) [44].

$\mathrm{RF}$, the precursor of FAD and FMN, is converted by riboflavin kinase (RFK) into FMN and FAD, which are essential cofactors of the phagocytic nicotinamide adenine dinucleotide phosphate (NADPH) oxidase 2 (Nox2). In particular, it has been shown that RF deficiency using conditional RFK knockout strains of mice impairs Nox2 priming. Such an effect may have implications for ROS production which impairs defence against Listeria monocytogene [51]. These data show that TNF priming of Nox2 represents a RF-dependent mechanism that is crucial for optimal ROS production in innate immune responses (Figure 4 ).

As mentioned above, RF plays a crucial role in Nox2. The experiment of Dey and Bishayi [49] showed that RF pre-treated macrophages lead to elevated levels of $\mathrm{H}_{2} \mathrm{O}_{2}, \mathrm{O}_{2}{ }^{-}$as well as ROS and cause direct oxidative damage to many pathogens (Figure 5). RF along with antibiotics balances ROS and inflammatory cytokines and controls $S$. aureus infection by boosting murine macrophage function and regulates inflammation [49].

Wooley and Sebrell have shown that RF-deficient mice are more susceptible to fetal experimental pneumococcus infection than control groups [52].

The deleterious toxic effects of many toxic substances have been linked to an increased production of free radicals and/or ROS. Some reports have indicated that RF has a protective effect against mitochondrial toxicity and lipodystrophy when in combination with stavudine or both stavudine and lamivudine in animal models [53].

\subsection{Photosensitizing Properties of RF}

As a photosensitizer, RF induces oxidative damage to light-exposed tissue by the degradation of proteins, unsaturated lipids, folate, thiamine and other vitamins. This is due to the triplet-excitation state of RF resulting from light exposure, which can then be deactivated by phenolic and N-heterocyclic amino acids as well as their compounds. The deactivation of triplet-excited state RF by oxygen under aerobic conditions is faster than by anaerobic conditions through polyunsaturated lipids. Carotenoids do not appear to have deactivation properties for the triplet-excited state of RF, while vitamin E and plant polyphenols deactivate triplet-excited state RF and, therefore, protect proteins and lipids from degradation. On the other hand, polyphenols and carotenoids have protective effects on the degradation processes brought by triplet-excited state RF, however by different mechanisms [1]. Since RF acts as a photosensitizer it can be used with Long-wave-length ultraviolet irradiation in order to inactivate many pathogens like HIV, pseudorabies virus, West Nile virus, parvovirus, E.coli, and Leishmanial protozoa [54-57].

\subsection{Cancer}

RF deficiency has been implicated as a risk factor for cancer in general, although this has not been satisfactorily established and proved in humans [7]. There have been several articles reporting results of randomized controlled trials of RF on risk of cancer incidence. There has been an experimental finding that high folate (B vitamin) intake may reduce breast cancer risk in Chinese women [58]. The results of a study that has investigated the effect of RF on 786-O cells indicated that RF at the high dose can inhibit cell viability and has a significant reduction in the level of tumor necrosis factor receptor 1 (TNFR1) in 786-O cells [59]. In a study carried out by Machado et al. [60] showing a strong inhibitory effect of RF on melanoma metastasis formation in lung of animal model. In addition, RF is 
likely to decrease risk of colorectal cancer (CRC) among women. Methylenetetrahydrofolate reductase (MTHFR) is FAD-dependent and low intake of RF may disturb this enzyme activity and related with CRC [61]. Moreover, in post-menopausal women, intake of RF and vitamin B-6 related to a decreased $\mathrm{CRC}$ risk [62]. Few significant associations between the intake of RF and the risk of ovarian cancer were observed [63].

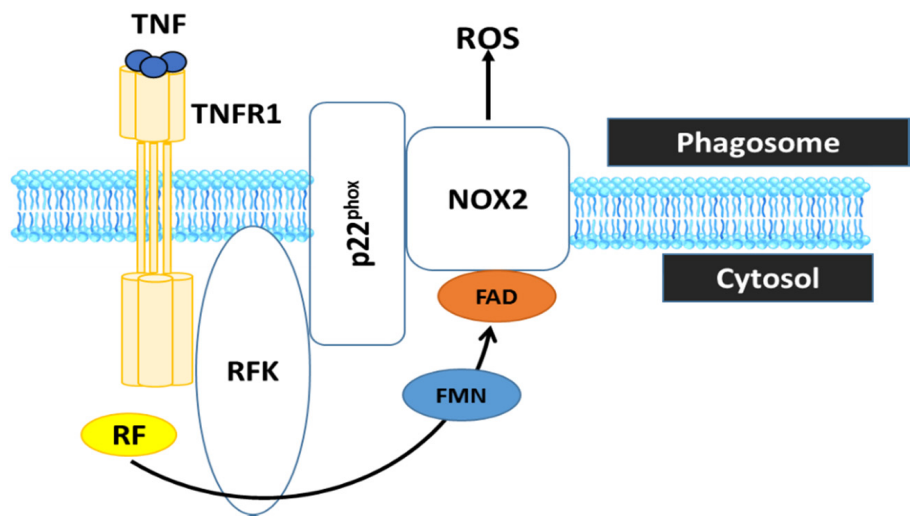

Figure 4. RF is converted by RFK into FMN and FAD, which is essential cofactor the phagocytic NADPH oxidase 2 (Nox2) to generate ROS. Therefore, RF deficiency is incapable of ROS production by the phagocyte Nox2, which is crucial to inactivate phagocytosed microbes and to regulate the inflammatory response in innate immune cells. TNF, tumor necrosis factor; TNFR1, tumor necrosis factor receptor 1 .

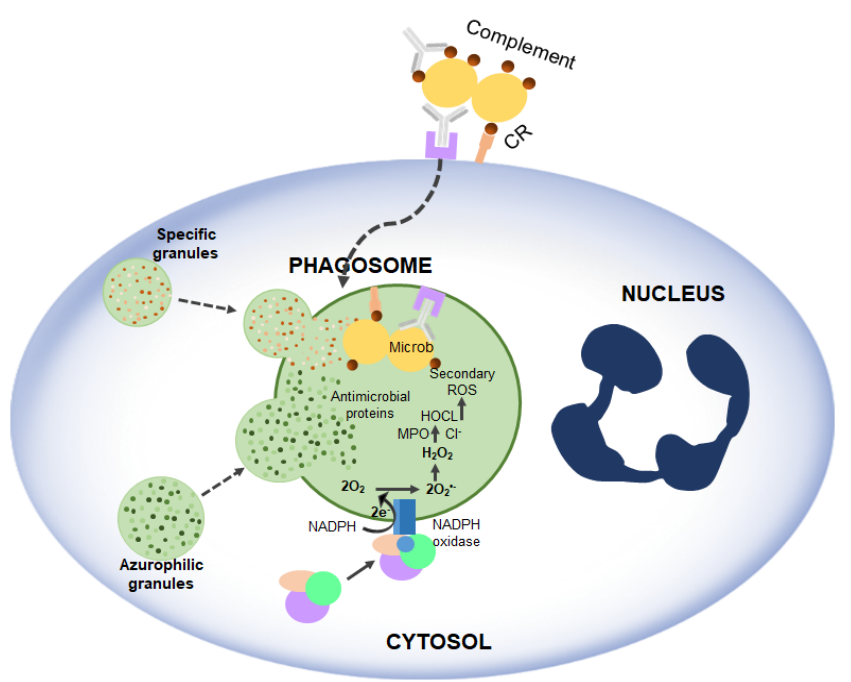

Figure 5. Activation of NADPH oxidase and microbicidal systems during phagocytosis. Complement and antibody receptors (CRs and FcRs) promote the uptake of micro-organisms by neutrophils, which, in turn, trigger the degranulation and production of ROS.

In female non-smokers, a higher intake of RF was correlated with a decrease the risk of lung cancer. The RF intake of $1.2 \mathrm{mg}$ per day was associated with a lower risk of developing lung cancer compared to an intake of $0.52 \mathrm{mg}$ per day [64]. There is a significant interest in RF in combination with thiamin, folate, and vitamin B12 from supplements and foods for a protective role in cervical carcinogenesis [65]. The importance of flavins in the folate metabolism as well as the combined protective effect of RF and folate is well known [66].

Further studies dealing with the RF doses are necessary to prove any efficacy in treatment such as cervical cancer or AIDS-related acidosis [3]. RF is associated with the inhibition in tumour growth in experimental animals and possibly in man; however, the regularity behind has not been discovered. 
The deficiency of RF increases the risk of cancer, while others propose an attenuating effect of some carcinogens [67]. A deficiency in RF can cause a disruption of the integrity of oesophageal epithelium and in some studies it is related to oesophageal cancer [68], while others relate to an increased susceptibility to cancer [69].

A high dose of RF intake showed a reverse effect of hepato-carcinogens in rodents [70]. One study proposed that a moderate amount of RF can initiate the extrinsic pathway of apoptosis. Higher levels of RF can trigger further cell death mechanisms like the intrinsic pathway by the action of down regulation of anti-apoptotic factors and by the upregulation of apoptotic factors (Figure 6) [71].

The overall outcomes in the available studies are optimistic but not yet convincing. There are further studies to be made to obtain more knowledge about the role and mechanism of action of vitamins and other micronutrients in terms of prevention and treatment of cancer. On the other hand, RF is considered to have an enormous capability to be used in improving the chemotherapeutic potential of anticancer drugs [72].

In addition, RF laurate has protective and therapeutic properties against radiotherapy-induced toxicity on human embryonic lung fibroblasts (Helf cells) [73].

The oxidative damage of cells from chemotherapeutic drugs can be ameliorated by RF administration. RF can improve the chemotherapeutic potential of major anticancer drugs like carbon tetrachloride $\left(\mathrm{CCL}_{4}\right)$ via decreasing the hepatic oxidative stress and the release of pro-inflammatory cytokine TNF- $\alpha$ from leukocytes in $\mathrm{CCl}_{4}$-induced hepatic injury [74].

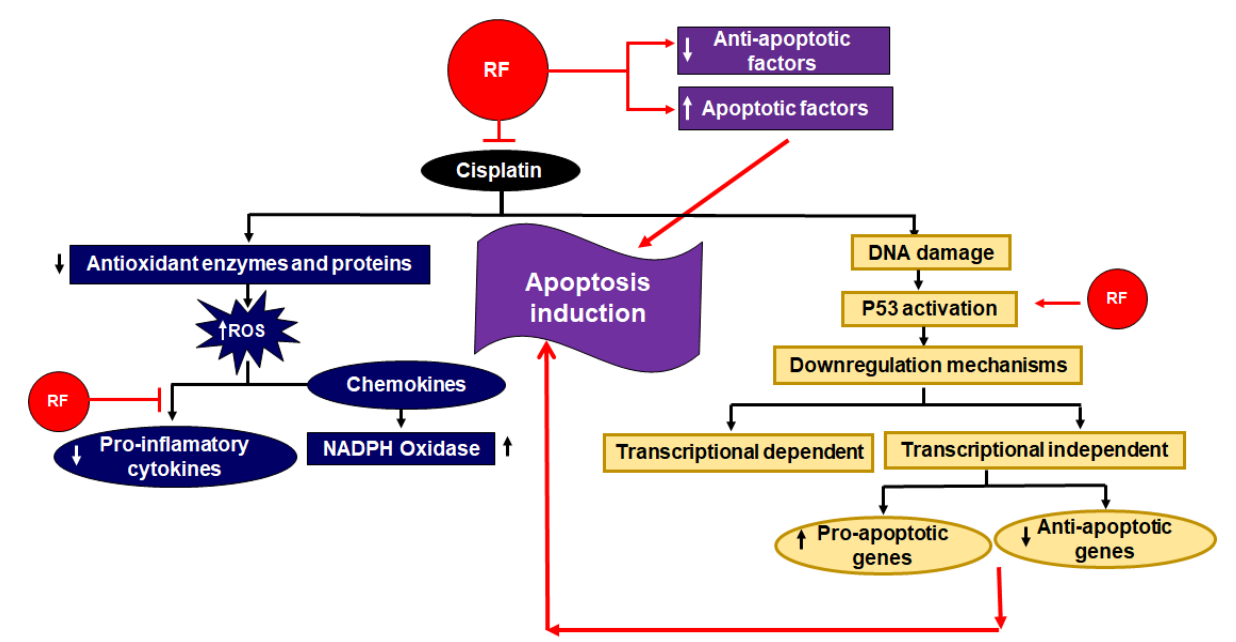

Figure 6. Role of RF as an adjuvant in cisplatin based chemo radiotherapy [75]. RF stimulates apoptotic factors and downregulates anti-apoptotic factors. Additionally, it activates p53, which also results in an amplification of apoptosis. The inhibitory effects of RF in respect to the deteriorate effect of cisplatin are also shown. On the one hand, it inhibits the downregulation of antioxidant enzymes and proteins; on the other, RF downregulates pro-inflammatory cytokines.

\subsection{Migraine}

Currently it is not clear how RF contributes to migraine prevention. However, the reduction in oxygen metabolism due to a mitochondrial dysfunction may play a role in migraine prevention since an increase in RF concentration might enhance the brain mitochondrial functions [76]. Studies have indicated a positive influence of RF in migraine prophylaxis, as RF is considered to play a potential role due to its attributes in the sense of safety, toleration and as an economically reasonable substance [77]. A clinical study reported that RF is an effective and low-cost prophylactic treatment in children and adolescents suffering from migraine [78]. In a study of migraine sufferers, RF combined with feverfew and magnesium showed a significant reduction in number of migraine attacks, migraine days and migraine index in the 3-month trial. When treatment response was compared, no significant 
differences were seen between the groups [79]. It has also been demonstrated that RF supplemented with magnesium and Q10 ameliorates migraine symptoms [80].

\subsection{Cataract}

Cataract formation is a result of protein aggregation which causes the lens to become cloudy. RF intake from food and supplements was associated with decreased risk of nuclear lens opacities [81]. Cataract formation in the general public seemed not to be associated with RF deficiency while in the elderly it might be increased due to a RF deficiency [82]. High dose of RF, $400 \mathrm{mg} / \mathrm{d}$, appears to have a preventive effect or some beneficial effects on the development of age-related cataracts [3]. RF concentration influences the GSH concentration in the lens, while GSH protects the lens against oxidative damage and cataract development. In total, $80 \%$ of the cataract patients showed a shortage of RF [83].

\subsection{Premenstrual Syndrome (PMS)}

Premenstrual syndrome (PMS) is a condition that refers to a complex of physical and psychological symptoms which occur during the luteal phase of the menstrual cycle and disappear when menstruation starts. An increased intake of RF from food sources was associated with a decrease in the risk of PMS. The intake of $2.52 \mathrm{mg}$ RF per day was observed to lead to a 35\% lower risk of developing PMS compared to the intake of $1.38 \mathrm{mg}$ per day [84].

\subsection{Bone}

Osteoporosis is a systemic skeletal disease. One of the most important factors to influence risk of fracture is vitamin intake. RF had an additive effect on ascorbate and $\beta$-glycerophosphate-induced osteoblast differentiation of MC3T3-E1 including intensifying G0/G arrest in pre-osteoblast cells [85].

\subsection{Neuropathy}

Indications have been made for RF being important in the early postnatal development of the brain [86]. The reduction in RF uptake and decrease in RF transporter protein (RFVT2) expression due to mutations in SLC52A2 gen has been illustrated. Patients with these mutations have shown significant and sustained clinical and biochemical improvements after high-dose oral RF therapy [87]. Moreover, $\mathrm{RF}$ co-treatment with selenium or vitamin $\mathrm{E}$ can have a protective effect on brain and microsomal membrane $\mathrm{Ca}^{2+}$-ATPase (MMCA) and oxidative damage caused by glyceryl trinitrate (GTN)-induced headaches in rat models. RF and selenium (SE) can decrease lipid peroxidation (LP) levels and increase glutathione and reduced glutathione levels in microsomal brains. The co-administration of RF and vitamin $\mathrm{E}$ induced a decrease in calcium and a decrease in brain and microsomal lipid peroxidation levels $[19,20]$. The brain and microsomal lipid peroxidation levels (LP) have been found to be higher in the GTN-induced rats with migraine headaches compared to healthy rats [19]; whereas SE orally pre-treated rats with or without RF were protected against GTN-induced brain oxidative toxicity, by inhibiting free radicals and MMCA activity and supporting the antioxidant effect of RF [19]. It has been demonstrated that RF plays a protective role in a time- and dose-dependent manner against excitotoxicity of cerebellar granule neurons induced by glutamate/NMDA in C57/B strain mice [21]. It has been shown by authors [22] that RF may have therapeutic potential for the treatment of traumatic brain injury. RF administration after frontal cortical contusion injury (CCI) in rats improved behavioural outcomes, reduced the number of glial fibrillary acidic protein $\left(\mathrm{GFAP}^{+}\right)$astrocytes, reduced brain oedema formation and reduced lesion size [22]. In addition, it is also suggested to combine RF and $\mathrm{MgCl}_{2}$ infusions, to be more effective in improving functional recovery after bilateral and unilateral cortical CCI in rats [23]. 


\subsection{Anemia}

RF contributes to blood cells formation as it plays a role in erythropoiesis, improves iron absorption and helps in the mobilization of ferritin from tissues [88]. The concentration of hemoglobin was able to be increased by RF supplementation. In an animal model, RF was also shown to enhance iron absorption [89], while RF deficiency increases the rate of gastrointestinal loss of iron and decreases the mobilization of iron from its stores [90].

A positive relation between RF intake and anemia in women, especially those below 50 years, was observed. Furthermore, a significant association between RF and iron intake in correspondence to the risk of anemia was detected. There have been cross-sectional studies to illustrate the link between RF intake and anemia, while prospective population studies are limited [91].

\subsection{Diabetes Mellitus}

Oxidative Stress is one of the major factors in the pathogenesis of type-2-diabetes mellitus (T2DM). The dietary intake of RF might lead to a reduction in diabetic complications because of the reduction in inflammatory processes triggered by oxidative stress and ROS formation. RF is indicated to have a positive effect on blood sugar. It plays a role in the absorption of sugar from the intestine and reduces hyperglycemia. It enhances the state of hyperglycaemias by increasing glucose uptake in skeletal muscles and white adipose tissue, as well as significantly ameliorating oxidative stress, tissue damage and cellular DNA damage in T2DM in mice. The ability of antioxidants to inhibit injury has raised the possibility of new therapeutic treatment for diabetic heart diseases. RF has shown promising beneficial effects on heart failure in type I diabetic cardiomyopathy in rats $[16,17]$.

\subsection{Cardiac Abnormalities}

$\mathrm{RF}$ as a single compound has shown promising results for protective actions in terms of cardiac abnormalities. Cardiac abnormalities could be avoided or reduced by using RF. RF may be combined with other compounds to have additive beneficial effects. RF combination with coenzyme Q10, niacin, selenium as CoRNS and Emblica officinalis has a protective effect on cardiac abnormalities in experimental atherosclerosis [18]. RF also reduces subsequent acute rejection and early graft oxidant stress significantly after allotransplantation and coronary allograft vasculopathy as results of cardiac ischemia-reperfusion. Pre-treatment with RF in a murine heart transplantation model can protect tissues from oxidative damage by decreasing myocardial lipid peroxidation, leukocyte infiltration, cytokine production, and cardiac allograft vasculopathy [34].

\subsection{Hypertension}

Hypertension is considered to be the leading risk factor for mortality worldwide [92]. It is estimated to be responsible for 8 million premature deaths per year [93]. A study has proposed an association of RF intake and blood pressure modulation. In animal studies, RF as supplementation did not provoke the side effects, but did provoke a significant systolic blood pressure reduction which was not age dependent between young and adult rats [94].

\section{Side Effects of Lack or Excess of RF}

RF deficiency has been comprehensively reviewed elsewhere [7]. RF is required in many oxidation-reduction reactions and, therefore, RF deficiency may affect many systems. RF is considered to be one of the most common vitamins with deficits in people of developing countries, particularly the ones with rice as their staple food. In those countries, important RF sources like milk and meat are not sufficiently consumed [95]. However, ariboflavinosis is not a common deficiency in most societies. RF deficiency is only measurable by quantifying the vitamin concentration in body fluids like blood plasma, serum, etc. [96] (Table 1). 
Ariboflavinosis in humans causes various symptoms like sore throat, hyperaemia, oedema of the oral and mucous membranes, cheilitis and glossitis, hair loss, inflammation of skin, cataract development, migraine and a decrease in $\mathrm{Hb}$. RF deficiency has shown an influence on the iron absorption, metabolism of tryptophan, mitochondrial function, brain and the metabolism of other vitamins. The Food and Nutrition Board 1998 published that a balanced diet meets the recommended intake of $1.4 \mathrm{mg}$ RF per day for an adult man. A study observed that approximately $60 \%$ of elderly people were at risk for RF deficiency [97]. The shortage of RF could also be a consequence of the use of some drugs, alcohol consumption, increased need of RF due to physiological conditions like pregnancy or breastfeeding or childhood etc. (Figure 7) [7,75,88].

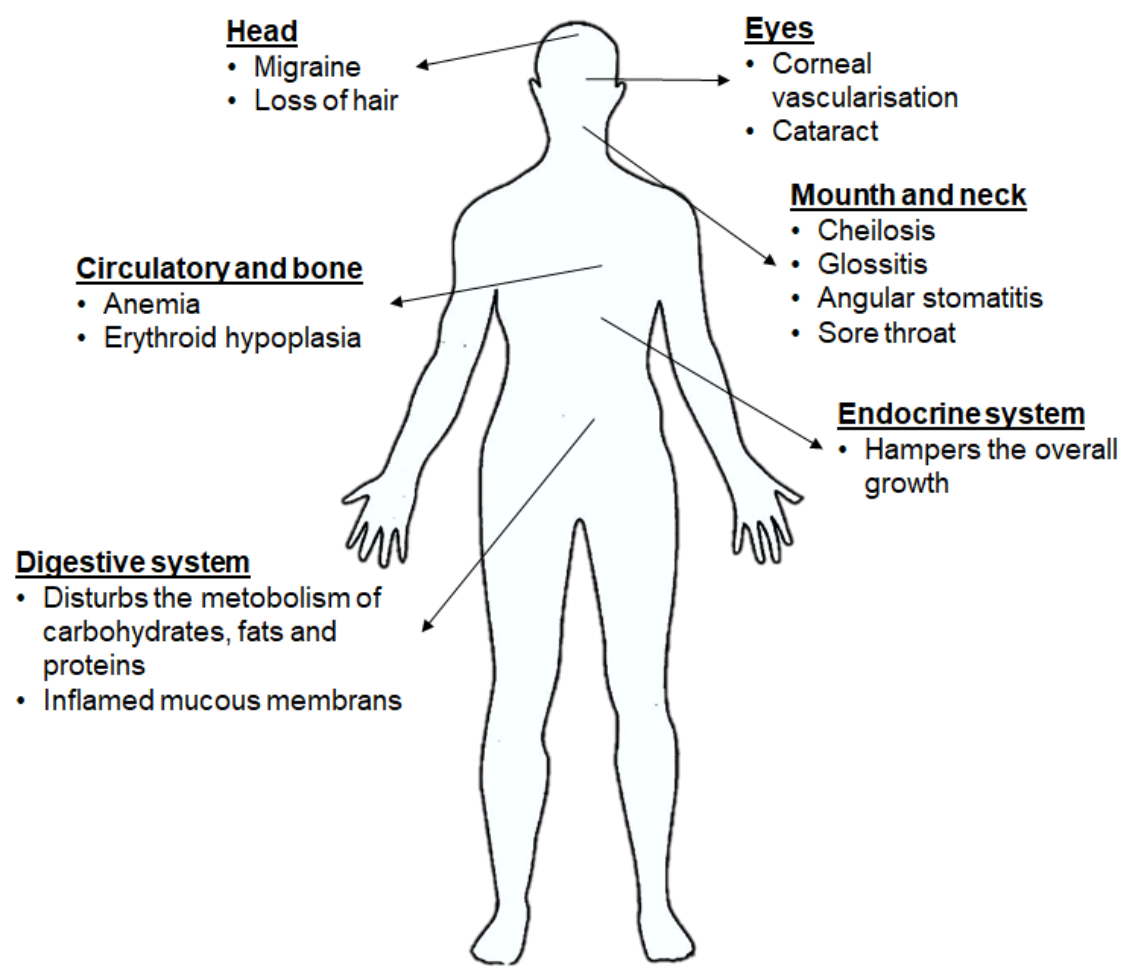

Figure 7. Implications of RF deficiency on health [75].

RF deficiency rarely occurs alone and is usually part of generalized vitamin B deficiency because of a poor diet or malabsorption. Oral supplementation of RF alone is poorly absorbed, with only $15 \%$ of bioavailability. RF can be destroyed by UV light exposure; UV therapy in infants with hyperbilirubinemia could cause RF deficiency [3].

\section{Mechanism of Antioxidant Protection}

RF has an antioxidant function that can destroy ROS [10]. The powerful antioxidant activity is derived from its role as precursor to FMN and FAD as important coenzymes required by a number of enzymes involved in oxidative metabolism, particularly glutathione oxidase. On the other hand, GR-which is a free radical scavenger-also needs FAD as a cofactor. The protective role of RF against various diseases has been described previously [98]. Several studies showed that RF is effective to reduce ROS in various diseases including anti-aging and it also helps to ameliorate the toxic effect of drugs in various treatments. Many studies investigated the antioxidant effect of some vitamins such as vitamin E, vitamin C, carotenoids and RF. RF effective mechanism has not been completely investigated. It acts as a coenzyme for redox enzymes in FAD and FMN forms and can have a potential effect on oxidative stress reduction as an antioxidant by prevention of lipid peroxidation and by attenuation of reperfusion oxidative injury. GR requires RF for its activity to convert GSSG to the GSH. 
FAD transports hydrogen from NADPH to GSSG to convert it into the GSH form (Figure 8). GSH acts intracellular as an endogenous antioxidant and deactivates ROS. Glutathione deactivates peroxides such as hydroperoxides by the action of GPx from GSH to lipid peroxide and produce GSSG and alcohol. Therefore, RF deficiency leads to an increase in lipid peroxidation.

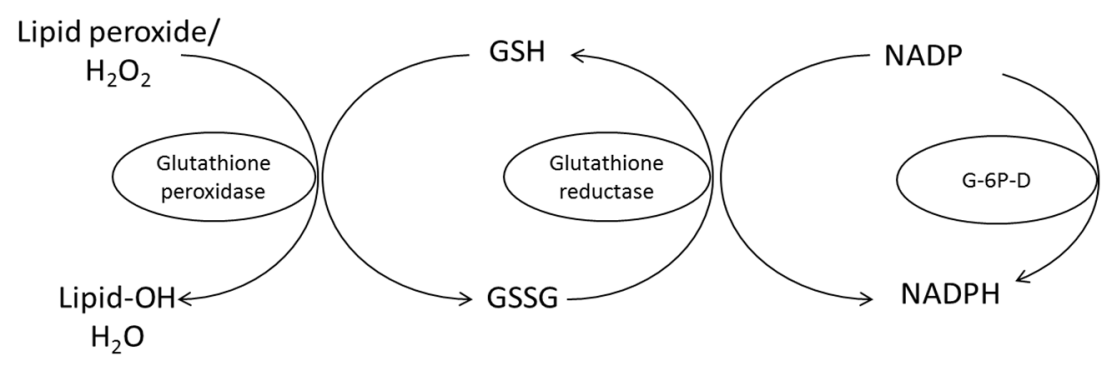

Figure 8. Conversion oxidized glutathione (GSSG) to the reduced form (GSH) by glutathione reductase requires RF in the FAD co-enzyme form for its activity. G-6P-D, glucose-6-phosphate dehydrogenase [98].

\section{Perspective Use of RF in Complementary Medicine: Administration via Functional Food and Nanocapsules}

\subsection{RF in Food}

Biotechnological application is used for fermented RF-enriched functional foods. Lactic acid bacteria, can synthesize or utilize during food fermentation, are considered for the production of vitamin-enriched food (Figure 9). Using L. lactis to produce fermented milk overcomes ariboflavinosis in a RF-deficiency rat model [99]. L. plantarum was used to produce fermented RF-enriched sourdough bread and pasta [100], soymilk [101], oat-based food [102]. L. fermentun was found to produce RF to fortify bread [103]. Furthermore, P. freudenreichii lead to an increase in RF content in yoghurt with P. freudenreichii [104] or fermented milk with this Propionibacterium species reverted ariboflavinosis in mouse [105].

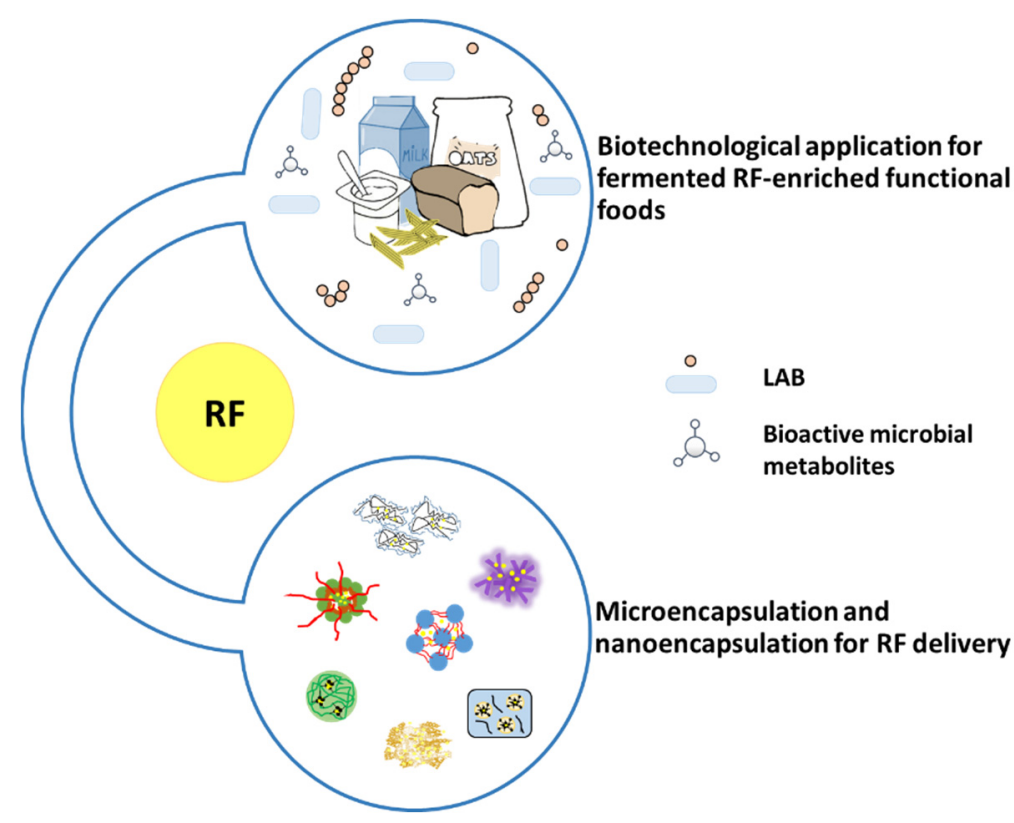

Figure 9. RF in functional food and encapsulation products.

\subsection{RF Encapsulation}

$\mathrm{RF}$ is sensitive to light, especially at high temperatures and in alkaline conditions [106]. In food process modifications, fortification or encapsulation has the potential to alter the stability of RF in food 
(Figure 9). Therefore, to maintain the level of this vitamin, these factors need a consideration for its stability. Encapsulation has been proposed as a solution for its chemical instability [107-109].

Micro/nano-encapsulation was used to solve RF chemical instability. Numerous encapsulating techniques are currently implemented and selected according to the physical and chemical properties of core materials and encapsulating agents. Some example methods used for RF micro/nano-encapsulation are shown in Table 5.

Blank whey microbeads manufactured using a cold-set gelation process, were placed in solutions of RF [109]. As the volume of microbeads added to the solution was increased, the uptake of the compounds increased, to a maximum of $57 \%$. The release kinetics of RF can be fitted by a pseudo first-order kinetic model very well. In addition, in vitro and in vivo release of RF from microbeads was evaluated [110]. In the first hour, the release of RF from dried microbeads was decreased in comparison to wet microbeads in gastric and intestinal settings, with $58 \%$ and $34 \%$, respectively. The in vivo release of RF from dried microbeads - microbeads fed to piglets were shown to be only partially degraded-demonstrating good resistance to gastrointestinal degradation after ingestion. These aspects led research interests towards dried whey microbeads able to effectively deliver these substances for oral delivery to the intestine.

Hydrogels of soy protein isolate (SPI) were prepared via high intensity ultrasound (HIU) and were cross-linked by transglutaminase (TGase) [111]. Ultrasound treatment resulted in decreasing the RF release from TSGRs in simulated intestinal fluid (SIF) and simulated gastric fluid (SGF) with or without digestive enzymes. In addition, both encapsulation efficiency and gelation yield increased after ultrasound treatment.

Azevedo et al. loaded RF in alginated-chitosan NPs prepared by ionic gelation [112]. The average size of nanoparticles with RF was $104 \pm 67 \mathrm{~nm}$ (PDI $0.32 \pm 0.07$ ) with a Zeta-potential of $-29.6 \pm 0.1 \mathrm{mV}$. The nanoparticles showed entrapment efficiency (EE\%) and loading capacity (LC) values of $56 \pm 6 \%$ and $2.2 \pm 0.6 \%$, respectively. The release profiles were affected by polymeric relaxation. In addition, the stability of alginate-chitosan was measured over a five-month period at $4{ }^{\circ} \mathrm{C}$ in solution.

Table 5. Techniques and characteristic of micro/nanoencapsulation of encapsulated RF.

\begin{tabular}{|c|c|c|c|c|c|}
\hline Encapsulation Techniques & $\begin{array}{c}\text { Wall } \\
\text { Material }\end{array}$ & Illustration of Characteristics & Purpose & Size & References \\
\hline Cold-set gelation & $\begin{array}{l}\text { Whey protein } \\
\text { isolated }\end{array}$ & $\frac{1}{s}$ wPI & $\begin{array}{l}\text { Proofing suitability of encapsulation system } \\
\text { for intestinal delivery using in vitro and } \\
\text { in vivo models }\end{array}$ & $1.8 \mathrm{~mm}$ & [11] \\
\hline $\begin{array}{l}\text { Cross-linking of HIU-treated } \\
\text { SPI with TGase }\end{array}$ & Soy protein isolated (SPI) & & $\begin{array}{l}\text { Demonstrating of HIU-treated SPI-TGase } \\
\text { cold gel for longer retention in the } \\
\text { gastrointestinal system }\end{array}$ & $3 \mathrm{~mm}$ & [111] \\
\hline Ionotropic gelation & $\begin{array}{l}\text { Alginate/chitosan } \\
\text { nanoparticles }\end{array}$ & 5 Alginate & $\begin{array}{l}\text { Establishing of alginate/chitosan nanoparticle } \\
\text { for controlled release in different temperature } \\
\text { and } \mathrm{pH} \text { conditions }\end{array}$ & $119.5 \pm 49.9 \mathrm{~nm}$ & [112] \\
\hline Ultrasonication & $\begin{array}{l}\text { Soy protein/dextran } \\
\text { nanogel }\end{array}$ & & $\begin{array}{l}\text { Providing basic design of soy protein/dextran } \\
\text { nanogel for effective and suitable carriers for } \\
\text { bioactive compounds }\end{array}$ & $143.3 \mathrm{~nm}$ & [113] \\
\hline Bioconjugation & $\begin{array}{l}\text { Phenylalanine ethyl } \\
\text { ester-alginate conjugated } \\
\text { (PEA) }\end{array}$ & $\begin{array}{l}\text { Agginate } \\
\text { Phenylalanine ester estyl }\end{array}$ & $\begin{array}{l}\text { Illustrating a sonication method of } \\
\text { self-assembled nanoparticles formed by PEA } \\
\text { conjugate without cytotoxicity against } \\
\text { cell lines }\end{array}$ & $200 \mathrm{~nm}$ & [114] \\
\hline Supercritical fluid technology & $\begin{array}{l}\text { Fully hydrogenated } \\
\text { canola oil }\end{array}$ & 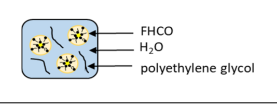 & $\begin{array}{c}\text { Evaluating surfactant and molecular weight } \\
\text { of stabilizer from supercritical fluid } \\
\text { technology for development of solid } \\
\text { lipid nanoparticles } \\
\end{array}$ & $104 \pm 5.7 \mathrm{~nm}$ & [115] \\
\hline $\begin{array}{l}\text { Coprecipitation-Crosslinking- } \\
\text { Dissolution technique } \\
\text { (CCD-technique) }\end{array}$ & Human serum albumin & in serum albumin & $\begin{array}{l}\text { Demonstrating a simple coprecipitation } \\
\text { method of albumin submicron particles with } \\
\text { good biocompatibility }\end{array}$ & $900 \pm 1000 \mathrm{~nm}$ & [116] \\
\hline
\end{tabular}

Jin et al. [113] encapsulated RF using modified soy protein/dextran with the range of $143.3 \mathrm{~nm}$ size. The EE\% and LC values of nanogels were up to $65.9 \%$ and up to $12 \%$, respectively. The release rate of RF was examined in SIF and SGF. Nanogels have a better sustained release in SGF than in SIF. 
Recently, Zhang et al. [114] produced phenylalanine ethyl ester-alginate conjugate (PEA) using EDC-NHS coupling reaction. Nano-encapsulated RF in PEA was synthesized via sonication. It was observed that the size of produced nanoparticles was $200 \mathrm{~nm}$, meanwhile the LC and EE\% were $3.53 \%$ and $91.48 \%$, respectively. RF-loaded PEA-nanoparticles displayed $\mathrm{pH}$-dependant release trend. By declining $\mathrm{pH}$, the release rate of $\mathrm{RF}$ decreased. Moreover, the cytotoxicity of these particles to Caco- 2 cells was used to investigate. There is no significant cytotoxicity against cell line in a wide range of concentration.

Solid lipid-based nanoparticles loaded with RF were prepared using fully hydrogenated canola oil-based lipids, sodium lauryl sulfate and polyethylene glycol as surfactant and stabilizer, respectively [115]. An LC of $12 \%$ to $48 \%$ RF was reported while bioactive loads varied from 0.09 to 0.73 $\mathrm{mg} / \mathrm{g}$, with particle sizes in the range of $105 \mathrm{~nm}$.

The Co-precipitation Crosslinking Dissolution technique (CCD-technique) was employed in the presence of human serum albumin (HSA) and RF to produce albumin submicron particles. The uniform peanut-like particles showed a narrow size distribution in the range of 0.9 to $1 \mu \mathrm{m}$ and a negative zeta-potential. The RF-albumin submicron particles revealed a good hemocompatibility [116].

\section{Conclusions}

RF is an important vitamin in the protection and treatment of various medical conditions. However, due to the few available studies on humans it is essential to have more data in terms of human clinical trials to conclude precise evidence and dosage information as recommendations for the treatment or prophylaxis of many diseases and conditions. The use of RF in fighting pathogens using UV-Light is a motivating approach, since it does not go along with adverse side effects. Through the consumption of functional RF-enriched foods, many diseases could possibly be prevented according to the currently available scientific evidence.

Author Contributions: Writing, editing, and original draft preparation, N.S.; writing, and review and editing, I.K.; review and editing, A.P.; conceptualization, review and editing, R.G.; supervision, conceptualization, and final approval of the manuscript, H.B. All authors have read and agreed to the published version of the manuscript.

Funding: This research was funded by Horizon 2020-MSCA-RISE 2018, Oxigenated (823879). N.S. held an academic development scholarship from the University of Phayao, Thailand. We acknowledge support from the German Research Foundation (DFG) and the Open Access Publication Funds of Charité-Universitätsmedizin Berlin and the Hans-Joachim Hoster Foundation.

Acknowledgments: We acknowledge discussions with Ciro Isidoro, Università del Piemonte Orientale "A. Avogadro", Novara, Italy.

Conflicts of Interest: The authors declare no conflict of interest.

\section{Abbreviations}

$\begin{array}{ll}\text { RF } & \text { Riboflavin } \\ \text { FMN } & \text { Flavin mononucleotide } \\ \text { FAD } & \text { Flavin adenine dinucleotide } \\ \text { SOD } & \text { Superoxide dismutase } \\ \text { ROS } & \text { Reactive oxygen species } \\ \text { GR } & \text { Glutathione reductase } \\ \text { GPx } & \text { Glutathione peroxidase } \\ \text { GSSG } & \text { Oxidized glutathione } \\ \text { GSH } & \text { Reduced glutathione } \\ \text { OGD } & \text { Oxygen glucose deprivation } \\ \text { LDH } & \text { Lactate dehydrogenase } \\ \text { Hb } & \text { Haemoglobin } \\ \text { TNF- } \alpha & \text { Tumor necrosis factor alpha } \\ \text { NO } & \text { Nitric oxide } \\ \text { NF- } \mathrm{B} B & \text { Nuclear factor factor kappa B } \\ \text { I B } & \text { Inhibitory kappa B }\end{array}$




\begin{tabular}{|c|c|}
\hline LPS & Lipopolysaccharide \\
\hline IL-6 & Interleukin-6 \\
\hline MCP-1 & Monocyte chemo attractant protein 1 \\
\hline MIP-2 & Macrophage inflammatory protein ()), \\
\hline HMGB1 & High-mobility group protein B1 \\
\hline MDA & Malondialdehyde level \\
\hline MPO & Myeloperoxidase \\
\hline CAT & Catalase \\
\hline HSP25 & Heat shock protein 25 \\
\hline RFK & Riboflavin Kinase \\
\hline NADPH & Nicotinamide adenine dinucleotide phosphate \\
\hline Nox2 & NADPH oxidase 2 \\
\hline TNFR1 & necrosis factor receptor 1 \\
\hline CRC & Colorectal cancer \\
\hline MTHFR & Methylenetetrahydrofolate reductase \\
\hline $\mathrm{CCL}_{4}$ & Carbon tetrachloride \\
\hline PMS & Premenstrual syndrome \\
\hline RFVT2 & RF transporter protein 2 \\
\hline MMCA & Microsomal membrane Ca2+-ATPase \\
\hline GTN & Glyceryl trinitrate \\
\hline SE & Selenium \\
\hline CCI & Cortical contusion injury linear dichroism \\
\hline GFAP+ & Glial fibrillary acidic protein \\
\hline T2DM & Type-2-diabetes mellitus \\
\hline PTL & Peritoneal leukocytes \\
\hline SPI & Soy protein isolate \\
\hline HIU & High intensity ultrasound \\
\hline TGase & Transglutaminase \\
\hline SIF & Simulated intestinal fluid \\
\hline SGF & Simulated gastric fluid \\
\hline $\mathrm{EE} \%$ & Entrapment efficiency \\
\hline $\mathrm{LC}$ & Loading capacity \\
\hline PEA & Phenylalanine ethyl ester-alginate conjugate \\
\hline CCD-technique & Coprecipitation-Crosslinking-Dissolution technique \\
\hline
\end{tabular}

\section{References}

1. Cardoso, D.R.; Libardi, S.H.; Skibsted, L.H. Riboflavin as a photosensitizer. Effects on human health and food quality. Food Funct. 2012, 3, 487-502. [CrossRef]

2. Dym, O.; Eisenberg, D. Sequence-structure analysis of FAD-containing proteins. Protein Sci. 2001, 10, 1712-1728. [CrossRef]

3. Buehler, B.A. Vitamin B2: Riboflavin. J. Evid. Based. Complementary Altern. Med. 2011, 16, 88-90. [CrossRef]

4. Zhang, Y.; Zhou, W.E.; Yan, J.Q.; Liu, M.; Zhou, Y.; Shen, X.; Ma, Y.L.; Feng, X.S.; Yang, J.; Li, G.H. A review of the extraction and determination methods of thirteen essential vitamins to the human body: An update from 2010. Molecules 2018, 23, 1484. [CrossRef]

5. Gul, W.N.; Anwar, Z.; Qadeer, K. Methods of analysis of riboflavin ( vitamin B2 ): A review. J. Pharm. Pharm. Sci. 2014, 2, 10-21.

6. Antal, I.P.; Bazel, Y.R.; Kormosh, Z.A. Electrochemical methods for determining group B vitamins. J. Anal. Chem. 2013, 68, 565-576. [CrossRef]

7. Powers, H.J. Riboflavin (vitamin B-2) and health. Am. J. Clin. Nutr. 2003, 77, 1352-1360. [CrossRef] [PubMed]

8. Toyosawa, T.; Suzuki, M.; Kodama, K.; Araki, S. Effects of intravenous infusion of highly purified vitamin B2 on lipopolysaccharide-induced shock and bacterial infection in mice. Eur. J. Pharmacol. 2004, 492, 273-280. [CrossRef] [PubMed] 
9. Toyosawa, T.; Suzuki, M.; Kodama, K.; Araki, S. Potentiation by amino acid of the therapeutic effect of highly purified vitamin B2 in mice with lipopolysaccharide-induced shock. Eur. J. Pharmacol. 2004, 493, 177-182. [CrossRef] [PubMed]

10. Toyasaki, T. Antioxidant effect of riboflavin in enzymic lipid peroxidation. J. Agric. Food Chem. 1992, 40, 1727-1730. [CrossRef]

11. Zou, Y.; Ruan, M.; Luan, J.; Feng, X.; Chen, S.; Chu, Z. Anti-aging effect of riboflavin via endogenous antioxidant in fruit fly Drosophila melanogaster. J. Nutr. Health Aging 2015, 21, 314-319. [CrossRef] [PubMed]

12. Cheung, I.M.Y.; Mcghee, C.N.J.; Sherwin, T. Beneficial effect of the antioxidant riboflavin on gene expression of extracellular matirix elements, antioxidants and oxidases in keratoconic stromal cells. Clin. Exp. Optom. 2014, 97, 349-355. [PubMed]

13. Sanches, S.C.; Naira, L.; Ramalho, Z.; Mendes-Braz, M.; Terra, V.A.; Cecchini, R.; Augusto, M.J.; Ramalho, F.S. Riboflavin (vitamin B-2) reduces hepatocellular injury following liver ischaemia and reperfusion in mice. Food Chem. Toxicol. 2014, 67, 65-71. [CrossRef] [PubMed]

14. Pompella, A.; Visvikis, A.; Paolicchi, A.; De Tata, V.; Casini, A.F. The changing faces of glutathione, a cellular protagonist. Biochem. Pharmacol. 2003, 66, 1499-1503. [CrossRef]

15. Tripathi, A.K.; Dwivedi, A.; Pal, M.K.; Rastogi, N.; Gupta, P.; Ali, S.; Prabhu Bh, M.; Kushwaha, H.N.; Singh Ray, R.; Singh, S.K.; et al. Attenuated neuroprotective effect of riboflavin under UV-B irradiation via miR-203/c-Jun signaling pathway in vivo and in vitro. J. Biomed. Sci. 2014, 21, 1-10. [CrossRef] [PubMed]

16. Wang, G.; Li, W.; Lu, X.; Zhao, X. Riboflavin alleviates cardiac failure in Type I diabetic cardiomyopathy. Heart Int. 2011, 6, 75-80. [CrossRef]

17. Alam, M.M.; Iqbal, S.; Naseem, I. Ameliorative effect of riboflavin on hyperglycemia, oxidative stress and DNA damage in type-2 diabetic mice: Mechanistic and therapeutic strategies. Arch. Biochem. Biophys. 2015, 584, 10-19. [CrossRef]

18. Indumathi, U.; Kanchana, K.; Sachdanandam, P. Protective role of coenzyme Q10, riboflavin, niacin, selenium (CoRNS) and Emblica officinalis on cardiac abnormalities in experimental atherosclerosis. Biomed. Prev. Nutr. 2013, 3, 313-318. [CrossRef]

19. Nazıroğlu, M.; Çelik, Ö.; Uğuz, A.C.; Bütün, A. Protective effects of riboflavin and selenium on brain microsomal $\mathrm{Ca} 2+-\mathrm{ATPase}$ and oxidative damage caused by glyceryl trinitrate in a rat headache model. Biol. Trace Elem. Res. 2014, 164, 72-79. [CrossRef]

20. Bütün, A.; Nazıroğlu, M.; Demirci, S.; Çelik, Ö.; Uğuz, A.C. Riboflavin and vitamin E increase brain calcium and antioxidants, and microsomal calcium-ATP-ase values in rat headache models induced by glyceryl trinitrate. J. Membr. Biol. 2015, 248, 205-213.

21. Lin, Y.; Desbois, A.; Jiang, S.; Hou, S.T. Group B vitamins protect murine cerebellar granule cells from glutamate/NMDA toxicity. Neuroreport 2004, 15, 2241-2244. [CrossRef] [PubMed]

22. Hoane, M.R.; Wolyniak, J.G.; Akstulewicz, S.L. Administration of riboflavin improves behavioral outcome and reduces edema formation and glial fibrillary acidic protein expression after traumatic brain injury. J. Neurotrauma 2005, 22, 1112-1122. [CrossRef] [PubMed]

23. Barbre, A.B.; Hoane, M.R. Magnesium and riboflavin combination therapy following cortical contusion injury in the rat. Brain Res. Bull. 2006, 69, 639-646. [CrossRef] [PubMed]

24. Seekamp, A.; Hultquist, D.E.; Till, G.O. Protection by vitamin B2 against oxidant-mediated acute lung injury. Inflammation 1999, 23, 449-460. [CrossRef]

25. Betz, A.L.; Ren, X.D.; Ennis, S.R.; Hultquist, D.E. Riboflavin reduces edema in focal cerebral ischemia. Acta Neurochir. Suppl. (Wien). 1994, 60, 314-317.

26. Mack, C.P.; Hultquist, D.E.; Shlafer, M. Myocardial flavin reductase and riboflavin: A potential role in decreasing reoxygenation injury. Biochem. Biophys. Res. Commun. 1995, 212, 35-40. [CrossRef] [PubMed]

27. Kulkarni, A.G.; Suryakar, A.N.; Sardeshmukh, A.S.; Rathi, D.B. Studies on biochemical changes with special reference to and antioxidants in malaria patients. Indian J. Clin. Biochem. 2003, 18, 136-149. [CrossRef]

28. Akompong, T.; Ghori, N.; Haldar, K. In vitro activity of riboflavin against the human malaria parasite Plasmodium falciparum. Antimicrob. Agents Chemother. 2000, 44, 88-96. [CrossRef]

29. George, B.O.; Ojegbemi, O. Oxidative stress and the effect of riboflavin supplementation in individuals with uncomplicated malaria infection. African J. Biotechnol. 2009, 8, 849-853.

30. Araki, S.; Suzuki, M.; Fujimoto, M.; Kimura, M. Enhancement of resistance to bacterial infection in mice by vitamin b2. J. Vet. Med. Sci. 1995, 57, 599-602. [CrossRef] 
31. Mazur-Bialy, A.I.; Buchala, B.; Plytycz, B. Riboflavin deprivation inhibits macrophage viability and activity a study on the RAW 264.7 cell line. Br. J. Nutr. 2013, 110, 509-514. [CrossRef]

32. Qureshi, A.A.; Reis, J.C.; Qureshi, N.; Papasian, C.J.; Morrison, D.C.; Schaefer, D.M. $\delta$-Tocotrienol and quercetin reduce serum levels of nitric oxide and lipid parameters in female chickens. Lipids Health Dis. 2011, 10, 39. [CrossRef] [PubMed]

33. Verdrengh, M.; Tarkowski, A. Riboflavin in innate and acquired immune responses. Inflamm. Res. 2005, 9, 390-393. [CrossRef] [PubMed]

34. Iwanaga, K.; Hasegawa, T.; Hultquist, D.E.; Harada, H.; Yoshikawa, Y.; Yanamadala, S.; Liao, H.; Visovatti, S.H.; Pinsky, D.J. Riboflavin-mediated reduction of oxidant injury, rejection, and vasculopathy after cardiac allotransplantation. Transplantation 2007, 83, 747-753. [CrossRef] [PubMed]

35. Qureshi, A.A.; Tan, X.; Reis, J.C.; Badr, M.Z.; Papasian, C.J.; Morrison, D.C.; Qureshi, N. Suppression of nitric oxide induction and pro-inflammatory cytokines by novel proteasome inhibitors in various experimental models. Lipids Health Dis. 2011, 10, 1-25. [CrossRef] [PubMed]

36. Bertollo, C.M.; Oliveira, A.C.P.; Rocha, L.T.S.; Costa, K.A.; Nascimento, E.B.; Coelho, M.M. Characterization of the antinociceptive and anti-inflammatory activities of riboflavin in different experimental models. Eur. J. Pharmacol. 2006, 547, 184-191. [CrossRef] [PubMed]

37. França, D.S.; Souza, A.L.S.; Almeida, K.R.; Dolabella, S.S.; Martinelli, C.; Coelho, M.M. B vitamins induce an antinociceptive effect in the acetic acid and formaldehyde models of nociception in mice. Eur. J. Pharmacol. 2001, 421, 157-164. [CrossRef]

38. Mazur-Bialy, A.I.; Majka, A.; Wojtas, L.; Kolaczkowska, E.; Plytycz, B. Strain-specific effects of riboflavin supplementation on zymosan-induced peritonitis in C57BL/6J, BALB/c and CBA mice. Life Sci. 2011, 88, 265-271. [CrossRef]

39. Mazur, A.I.; Natorska, J.; Wypasek, E.; Kołaczkowska, E.; Płytycz, B. Anti-inflammatory effects of riboflavin and morphine on zymosan-induced peritonitis in Swiss mice. Cent. J. Immunol. 2008, 33, 98-101.

40. Mazur-Bialy, A.I.; Kolaczkowska, E.; Plytycz, B. Modulation of zymosan-induced peritonitis by riboflavin co-injection, pre-injection or post-injection in male Swiss mice. Life Sci. 2012, 91, 1351-1357. [CrossRef]

41. Granados-Soto, V.; Terán-Rosales, F.; Rocha-González, H.I.; Reyes-García, G.; Medina-Santillán, R.; Rodríguez-Silverio, J.; Flores-Murrieta, F.J. Riboflavin reduces hyperalgesia and inflammation but not tactile allodynia in the rat. Eur. J. Pharmacol. 2004, 492, 35-40. [CrossRef]

42. Toyosawa, T.; Suzuki, M.; Kodama, K.; Araki, S. Highly Purified Vitamin B2 Presents a Promising Therapeutic Strategy for Sepsis and Septic Shock. Infect. Immun. 2004, 72, 1820-1823. [CrossRef] [PubMed]

43. Kodama, K.; Suzuki, M.; Toyosawa, T.; Araki, S. Inhibitory mechanisms of highly purified vitamin B2 on the productions of proinflammatory cytokine and NO in endotoxin-induced shock in mice. Life Sci. 2005, 78, 134-139. [CrossRef] [PubMed]

44. Shih, C.K.; Chen, C.M.; Chen, C.Y.O.; Liu, J.F.; Lin, H.W.; Chou, H.T.; Li, S.C. Riboflavin protects mice against liposaccharide-induced shock through expression of heat shock protein 25. Food Chem. Toxicol. 2010, 48, 1913-1918. [CrossRef] [PubMed]

45. Al-Harbi, N.O.; Imam, F.; Nadeem, A.; Al-Harbi, M.M.; Korashy, H.M.; Sayed-Ahmed, M.M.; Hafez, M.M.; Al-Shabanah, O.A.; Nagi, M.N.; Bahashwan, S. Riboflavin attenuates lipopolysaccharide-induced lung injury in rats. Toxicol. Mech. Methods 2015, 25, 417-423. [CrossRef] [PubMed]

46. Mazur-bialy, A.I.; Pochec, E. HMGB1 inhibition during zymosan-induced inflammation: The potential therapeutic action of riboflavin. Arch. Immunol. Ther. Exp. 2015, 1-6. [CrossRef]

47. Chen, X.-H.; Yin, Y.-J.; Zhang, J.-X. Sepsis and immune response. World J. Emerg. Med. 2011, 2, 88-92. [CrossRef] [PubMed]

48. Mal, P.; Ghosh, D.; Bandyopadhyay, D.; Dutta, K.; Bishayi, B. Ampicillin alone and in combination with riboflavin modulates Staphylococcus aureus infection induced septic arthritis in mice. Indian J. Exp. Biol. 2012, 50, 677-689.

49. Dey, S.; Bishayi, B. Riboflavin along with antibiotics balances reactive oxygen species and inflammatory cytokines and controls Staphylococcus aureus infection by boosting murine macrophage function and regulates inflammation. J. Inflamm. 2016, 13, 36. [CrossRef]

50. Mal, P.; Dutta, K.; Bandyopadhyay, D.; Basu, A.; Khan, R.; Bishayi, B. Azithromycin in combination with riboflavin decreases the severity of Staphylococcus aureus infection induced septic arthritis by modulating the production of free radicals and endogenous cytokines. Inflamm. Res. 2013, 62, 259-273. [CrossRef] 
51. Schramm, M.; Wiegmann, K.; Schramm, S.; Gluschko, A.; Herb, M.; Utermöhlen, O.; Krönke, M. Riboflavin (vitamin B2) deficiency impairs NADPH oxidase 2 (Nox2) priming and defense against Listeria monocytogenes. Eur. J. Immunol. 2014, 44, 728-741. [CrossRef] [PubMed]

52. Wooley, J.G.; Sebrell, W. Nutritional deficiency and infection: I. influence of riboflavin or thiamin deficiency on fatal experimental pneumococcal infection in white mice. Public Health Rep. 1942, 57, 149-161. [CrossRef]

53. Thaimuta, Z.L. Riboflavin protective role against mitochondrial toxicity and lipodystrophy due to stavudine and lamivudine. Ph.D. Thesis, University of Nairobi, Eldoret, Kenya, 2014.

54. Corbin, F. Pathogen inactivation of blood components: Current status and introduction of an approach using riboflavin as a photosensitizer. Int. J. Hematol. 2002, 76 (Suppl. S2), 253-257. [CrossRef] [PubMed]

55. Ruane, P.H.; Edrich, R.; Gampp, D.; Keil, S.D.; Leonard, R.L.; Goodrich, R.P. Photochemical inactivation of selected viruses and bacteria in platelet concentrates using riboflavin and light. Transfusion 2004, 44, 877-885. [CrossRef] [PubMed]

56. Cardo, L.J.; Rentas, F.J.; Ketchum, L.; Salata, J.; Harman, R.; Melvin, W.; Weina, P.J.; Mendez, J.; Reddy, H.; Goodrich, R. Pathogen inactivation of Leishmania donovani infantum in plasma and platelet concentrates using riboflavin and ultraviolet light. Vox Sang. 2006, 90, 85-91. [CrossRef] [PubMed]

57. Pelletier, J.P.R.; Transue, S.; Snyder, E.L. Pathogen inactivation techniques. Best Pract. Res. Clin. Haematol. 2006, 19, 205-242. [CrossRef]

58. Shrubsole, M.J.; Shu, X.O.; Li, H.L.; Cai, H.; Yang, G.; Gao, Y.T.; Gao, J.; Zheng, W. Dietary B vitamin and methionine intakes and breast cancer risk among Chinese women. Am. J. Epidemiol. 2011, 173, 1171-1182. [CrossRef]

59. Chaves Neto, A.H.; Pelizzaro-Rocha, K.J.; Fernandes, M.N.; Ferreira-Halder, C.V. Antitumor activity of irradiated riboflavin on human renal carcinoma cell line 786-O. Tumor Biol. 2015, 36, 595-604. [CrossRef]

60. Machado, D.; Shishido, S.M.; Queiroz, K.C.S.; Oliveira, D.N.; Faria, A.L.C.; Catharino, R.R.; Spek, C.A.; Ferreira, C.V. Irradiated riboflavin diminishes the aggressiveness of melanoma in vitro and in vivo. PLoS ONE 2013, 8, 1-12. [CrossRef]

61. De Vogel, S.; Dindore, V.; van Engeland, M.; Goldbohm, R.A.; van den Brandt, P.A.; Weijenberg, M.P. Dietary folate, methionine, riboflavin, and vitamin B-6 and risk of sporadic colorectalc cancer. J. Nutr. 2008, 138, 2372-2378. [CrossRef]

62. Zschäbitz, S.; Cheng, T.D.; Neuhouser, M.L.; Zheng, Y.; Ray, R.M.; Miller, J.W.; Song, X.; Maneval, D.R.; Beresford, S.A.A.; Lane, D.; et al. B vitamin intakes and incidence of colorectal cancer: Results from the women's health initiative observational study cohort. Am. J. Clin. Nutr. 2013, 97, 332-343.

63. Kabat, G.C.; Miller, A.B.; Jain, M.; Rohan, T.E. Dietary intake of selected B vitamins in relation to risk of major cancers in women. Br. J. Cancer 2008, 99, 816-821. [CrossRef] [PubMed]

64. Takata, Y.; Cai, Q.; Beeghly-Fadiel, A.; Li, H.; Shrubsole, M.J.; Ji, B.T.; Yang, G.; Chow, W.H.; Gao, Y.T.; Zheng, W.; et al. Dietary B vitamin and methionine intakes and lung cancer risk among female never smokers in China. Cancer Causes Control 2012, 23, 1965-1975. [CrossRef] [PubMed]

65. Hernandez, B.Y.; McDuffie, K.; Wilkens, L.R.; Kamemoto, L.; Goodman, M.T. Diet and premalignant lesions of the cervix: Evidence of a protective role for folate, riboflavin, thiamin, and vitamin B12. Cancer Causes Control 2003, 14, 859-870. [CrossRef]

66. Powers, H.J. Interaction among folate, riboflavin, genotype, and cancer, with reference to colorectal and cervical cancer. J. Nutr. 2005, 135, 2960S-2966S. [CrossRef]

67. Rivlin, R.S. Riboflavin and cancer: A review. Cancer Res. 1973, 33, 1977-1986.

68. Foy, H.; Kondi, A.; Verjee, Z.H.M. Relation of riboflavin deficiency to corticosteroid metabolism and red cell hypoplasia in baboons. J. Nutr. 1972, 102, 571-582. [CrossRef]

69. Bareford, L.M.; Phelps, M.A.; Foraker, A.B.; Swaan, P.W. Intracellular processing of riboflavin in human breast cancer cells. Mol. Pharm. 2008, 5, 839-848. [CrossRef]

70. Webster, R.P.; Gawde, M.D.; Bhattacharya, R.K. Modulation of carcinogen-induced DNA damage and repair enzyme activity by dietary riboflavin. Cancer Lett. 1996, 98, 129-135. [CrossRef]

71. Hassan, I.; Chibber, S.; Naseem, I. Vitamin B2: A promising adjuvant in cisplatin based chemoradiotherapy by cellular redox management. Food Chem. Toxicol. 2013, 59, 715-723. [CrossRef]

72. Naseem, I.; Hassan, I.; Alhazza, I.M.; Chibber, S. Protective effect of riboflavin on cisplatin induced toxicities: A gender-dependent study. J. Trace Elem. Med. Biol. 2015, 29, 303-314. [CrossRef] [PubMed] 
73. Xuan, Z.; An, Y.; Yang, D.; Wang, S.; Xu, Q.; Yuan, S. Exploration of the protection of riboflavin laurate on oral mucositis induced by chemotherapy or radiotherapy at the cellular level: What is the leading contributor? Int. J. Mol. Sci. 2013, 14, 4722-4733. [CrossRef] [PubMed]

74. Al-Harbi, N.O.; Imam, F.; Nadeem, A.; Al-Harbi, M.M.; Iqbal, M.; Ahmad, S.F. Carbon tetrachloride-induced hepatotoxicity in rat is reversed by treatment with riboflavin. Int. Immunopharmacol. 2014, 21, 383-388. [CrossRef]

75. Thakur, K.; Tomar, S.K.; Singh, A.K.; Mandal, S.; Arora, S.; Division, D.M.; Division, D.T.; Division, D.C.; Microbiology, D. Riboflavin and health: A review of recent human research. Crit. Rev. Food Sci. Nutr. 2017, 57, 3650-3660. [CrossRef] [PubMed]

76. Sparaco, M.; Feleppa, M.; Lipton, R.B.; Rapoport, A.M.; Bigal, M.E. Mitochondrial dysfunction and migraine: Evidence and hypotheses. Cephalalgia 2006, 26, 361-372. [CrossRef] [PubMed]

77. Sherwood, M.; Goldman, R.D. Effectiveness of riboflavin in pediatric migraine prevention. Can. Fam. Physician 2014, 60, 244-246. [PubMed]

78. Condó, M.; Posar, A.; Arbizzani, A.; Parmeggiani, A. Riboflavin prophylaxis in pediatric and adolescent migraine. J. Headache Pain 2009, 10, 361-365. [CrossRef]

79. Maizels, M.; Blumenfeld, A.; Burchette, R. A combination of riboflavin, magnesium, and feverfew for migraine prophylaxis: A randomized trial. Headache 2004, 44, 885-890. [CrossRef]

80. Gaul, C.; Diener, H.-C.; Danesch, U. Improvement of migraine symptoms with a proprietary supplement containing riboflavin, magnesium and Q10: A randomized, placebo-controlled, double-blind, multicenter trial. J. Headache Pain 2015, 16, 516. [CrossRef]

81. Jacques, P.F.; Chylack, L.T.; Hankinson, S.E.; Khu, P.M.; Rogers, G.; Friend, J.; Tung, W.; Wolfe, J.K.; Padhye, N.; Willett, W.C.; et al. Long-term nutrient intake and early age-related nuclear lens opacities. Arch. Ophthalmol. 2001, 119, 1009-1019. [CrossRef]

82. Skalka, H.W.; Prchal, J.T. Cataracts and riboflavin deficiency. Am. J. Clin. Nutr. 1981, 34, 861-863. [CrossRef] [PubMed]

83. SEETHARAM BHAT, K. Nutritional status of thiamin riboflavin and pyridoxine in cataract patients. Nutr. Rep. Int. 1987, 36, 685-692.

84. Chocano-bedoya, P.O.; Manson, J.E.; Hankinson, S.E.; Willett, W.C.; Johnson, S.R.; Chasan-taber, L.; Ronnenberg, A.G.; Bigelow, C.; Bertone-johnson, E.R. Dietary B vitamin intake and incident premenstrual syndrome. Am. J. Clin. Nutr. 2011, 93, 1080-1086. [CrossRef] [PubMed]

85. Chaves Neto, A.H.; Yano, C.L.; Paredes-Gamero, E.J.; Machado, D.; Justo, G.Z.; Peppelenbosch, M.P.; Ferreira, C.V. Riboflavin and photoproducts in MC3T3-E1 differentiation. Toxicol. Vitr. 2010, 24, 1911-1919. [CrossRef] [PubMed]

86. Ogunleye, A.J.; Odutuga, A.A. The effect of riboflavin deficiency on cerebrum and cerebellum of developing rat brain. J. Nutr. Sci. Vitaminol. (Tokyo). 1989, 35, 193-197. [CrossRef]

87. Foley, A.R.; Menezes, M.P.; Pandraud, A.; Gonzalez, M.A.; Al-Odaib, A.; Abrams, A.J.; Sugano, K.; Yonezawa, A.; Manzur, A.Y.; Burns, J.; et al. Treatable childhood neuronopathy caused by mutations in riboflavin transporter RFVT2. Brain A J. Neurol. 2014, 137, 44-56. [CrossRef]

88. Boisvert, W.A.; Castañeda, C.; Mendoza, I.; Langeloh, G.; Solomons, N.W.; Gershoff, S.N.; Russell, R.M. Prevalence of riboflavin deficiency among Guatemalan elderly people and its relationship to milk intake. Am. J. Clin. Nutr. 1993, 58, 85-90. [CrossRef]

89. Powers, H.J.; Weaver, L.T.; Austin, S.; Beresford, J.K. A proposed intestinal mechanism for the effect of riboflavin deficiency on iron loss in the rat. Br. J. Nutr. 1993, 69, 553-561. [CrossRef]

90. Powers, H.J.; Bates, C.J.; Prentice, A.M.; Lamb, W.H.; Jepson, M.; Bowman, H. The relative effectiveness of iron and iron with riboflavin in correcting a microcytic anaemia in men and children in rural Gambia. Hum. Nutr. Clin. Nutr. 1983, 37, 413-425.

91. Powers, H.J.; Hill, M.H.; Mushtaq, S.; Dainty, J.R.; Majsak-Newman, G.; Williams, E.A. Correcting a marginal riboflavin deficiency improves hematologic status in young women in the United Kingdom (RIBOFEM). Am. J. Clin. Nutr. 2011, 93, 1274-1284. [CrossRef]

92. Lopez, A.D.; Mathers, C.D.; Ezzati, M.; Jamison, D.T.; Murray, C.J. Global and regional burden of disease and risk factors, 2001: Systematic analysis of population health data. Lancet 2006, 367, 1747-1757. [CrossRef]

93. Lawes, C.M.M.; Vander Hoorn, S.; Rodgers, A. Global burden of blood-pressure-related disease, 2001. Lancet 2008, 371, 1513-1518. [CrossRef] 
94. França, C.F.; Vianna, L.M. The response of young and adult rats to the riboflavin supplementation. Braz. Arch. Biol. Technol. 2010, 53, 855-860. [CrossRef]

95. Leblanc, J.G.; Laiño, J.E.; del Valle, M.J.; Vannini, V.; van Sinderen, D.; Taranto, M.P.; de Valdez, G.F.; de Giori, G.S.; Sesma, F. B-Group vitamin production by lactic acid bacteria-Current knowledge and potential applications. J. Appl. Microbiol. 2011, 111, 1297-1309. [CrossRef]

96. Mensink, G.B.M.; Fletcher, R.; Gurinovic, M.; Huybrechts, I.; Lafay, L.; Serra-Majem, L.; Szponar, L.; Tetens, I.; Verkaik-Kloosterman, J.; Baka, A.; et al. Mapping low intake of micronutrients across Europe. Br. J. Nutr. 2013, 110, 755-773. [CrossRef]

97. Flynn, A.; Moreiras, O.; Stehle, P.; Fletcher, R.J.; Müller, D.J.G.; Rolland, V. Vitamins and minerals: A model for safe addition to foods. Eur. J. Nutr. 2003, 42, 118-130. [CrossRef]

98. Ashoori, M.; Saedisomeolia, A. Riboflavin (vitamin B2) and oxidative stress: A review. Br. J. Nutr. 2014, 111, 1985-1991. [CrossRef]

99. LeBlanc, J.G.; Burgess, C.; Sesma, F.; de Giori, G.S.; van Sinderen, D. Ingestion of milk fermented by genetically modified Lactococcus lactis improves the riboflavin status of deficient rats. J. Dairy Sci. 2005, 88, 3435-3442. [CrossRef]

100. Capozzi, V.; Menga, V.; Digesù, A.M.; De Vita, P.; Van Sinderen, D.; Cattivelli, L.; Fares, C.; Spano, G. Biotechnological production of vitamin B2-enriched bread and pasta. J. Agric. Food Chem. 2011, 59, 8013-8020. [CrossRef]

101. Juarez del Valle, M.; Laiño, J.E.; Savoy de Giori, G.; LeBlanc, J.G. Riboflavin producing lactic acid bacteria as a biotechnological strategy to obtain bio-enriched soymilk. Food Res. Int. 2014, 62, 1015-1019. [CrossRef]

102. Russo, P.; de Chiara, M.L.V.; Capozzi, V.; Arena, M.P.; Amodio, M.L.; Rascón, A.; Dueñas, M.T.; López, P.; Spano, G. Lactobacillus plantarum strains for multifunctional oat-based foods. LWT Food Sci. Technol. 2016, 68, 288-294. [CrossRef]

103. Russo, P.; Capozzi, V.; Arena, M.P.; Spadaccino, G.; Dueñas, M.T.; López, P.; Fiocco, D.; Spano, G. Riboflavin-overproducing strains of Lactobacillus fermentum for riboflavin-enriched bread. Appl. Microbiol. Biotechnol. 2014, 98, 3691-3700. [CrossRef] [PubMed]

104. Burgess, C.M.; Smid, E.J.; Rutten, G.; van Sinderen, D. A general method for selection of riboflavin-overproducing food grade micro-organisms. Microb. Cell Fact. 2006, 5, 1-12. [CrossRef] [PubMed]

105. LeBlanc, J.G.; Rutten, G.; Bruinenberg, P.; Sesma, F.; de Giori, G.S.; Smid, E.J. A novel dairy product fermented with Propionibacterium freudenreichii improves the riboflavin status of deficient rats. Nutrition 2006, 22, 645-651. [CrossRef]

106. Berry Ottaway, P. Stability of vitamins during food processing and storage. In Chemical Deterioration and Physical Instability of Food and Beverages; Elsevier: Amsterdam, The Netherlands, 2010; pp. 539-560.

107. Bou, R.; Cofrades, S.; Jiménez-Colmenero, F. Physicochemical properties and riboflavin encapsulation in double emulsions with different lipid sources. LWT Food Sci. Technol. 2014, 59, 621-628. [CrossRef]

108. Chen, L.; Subirade, M. Alginate-whey protein granular microspheres as oral delivery vehicles for bioactive compounds. Biomaterials 2006, 27, 4646-4654. [CrossRef]

109. Chen, L.; Subirade, M. Effect of preparation conditions on the nutrient release properties of alginate-whey protein granular microspheres. Eur. J. Pharm. Biopharm. 2007, 65, 354-362. [CrossRef]

110. O’Neill, G.J.; Jacquier, J.C.; Mukhopadhya, A.; Egan, T.; O’Sullivan, M.; Sweeney, T.; O'Riordan, E.D. In vitro and in vivo evaluation of whey protein hydrogels for oral delivery of riboflavin. J. Funct. Foods 2015, 19, 512-521. [CrossRef]

111. Hu, H.; Zhu, X.; Hu, T.; Cheung, I.W.Y.; Pan, S.; Li-Chan, E.C.Y. Effect of ultrasound pre-treatment on formation of transglutaminase-catalysed soy protein hydrogel as a riboflavin vehicle for functional foods. J. Funct. Foods 2015, 19, 182-193. [CrossRef]

112. Azevedo, M.A.; Bourbon, A.I.; Vicente, A.A.; Cerqueira, M.A. Alginate/chitosan nanoparticles for encapsulation and controlled release of vitamin B2. Int. J. Biol. Macromol. 2014, 71, 141-146. [CrossRef]

113. Jin, B.; Zhou, X.; Li, X.; Lin, W.; Chen, G.; Qiu, R. Self-assembled modified soy protein/dextran nanogel induced by ultrasonication as a delivery vehicle for riboflavin. Molecules 2016, 21, 282. [CrossRef] [PubMed]

114. Zhang, P.; Zhao, S.R.; Li, J.X.; Hong, L.; Raja, M.A.; Yu, L.J.; Liu, C.G. Nanoparticles based on phenylalanine ethyl ester-alginate conjugate asvVitamin B2 delivery system. J. Biomater. Appl. 2016, 31, 13-22. [CrossRef] [PubMed] 
115. Couto, R.; Alvarez, V.; Temelli, F. Encapsulation of vitamin B2 in solid lipid nanoparticles using supercritical CO2. J. Supercrit. Fluids 2017, 120, 432-442. [CrossRef]

116. Suwannasom, N.; Smuda, K.; Kloypan, C.; Kaewprayoon, W.; Baisaeng, N.; Prapan, A.; Chaiwaree, S.; Georgieva, R.; Bäumler, H.; Suwannasom, N.; et al. Albumin Submicron Particles with Entrapped Riboflavin-Fabrication and Characterization. Nanomaterials 2019, 9, 482. [CrossRef]

(C) 2020 by the authors. Licensee MDPI, Basel, Switzerland. This article is an open access article distributed under the terms and conditions of the Creative Commons Attribution (CC BY) license (http://creativecommons.org/licenses/by/4.0/). 